\title{
Temporal variability and sources of VOCs in urban areas of the eastern Mediterranean
}

\author{
Christos Kaltsonoudis $^{1,2}$, Evangelia Kostenidou ${ }^{1}$, Kalliopi Florou ${ }^{1,2}$, Magda Psichoudaki ${ }^{1,2}$, and Spyros N. Pandis ${ }^{1,2,3}$ \\ ${ }^{1}$ Institute of Chemical Engineering Sciences, ICE-HT, Patras, 26500, Greece \\ ${ }^{2}$ Department of Chemical Engineering, University of Patras, Patras, 26504, Greece \\ ${ }^{3}$ Department of Chemical Engineering, Carnegie Mellon University, Pittsburgh, 15213, USA
}

Correspondence to: Spyros N. Pandis (spyros@chemeng.upatras.gr)

Received: 26 April 2016 - Published in Atmos. Chem. Phys. Discuss.: 19 May 2016

Revised: 20 September 2016 - Accepted: 23 October 2016 - Published: 29 November 2016

\begin{abstract}
During the summer of 2012 volatile organic compounds (VOCs) were monitored by proton transfer reaction mass spectrometry (PTR-MS) in urban sites, in Athens and Patras, two of the largest cities in Greece. Also, during the winter of 2013, PTR-MS measurements were conducted in the center of the city of Athens. Positive matrix factorization (PMF) was applied to the VOC measurements to gain insights about their sources.

In summer most of the measured VOCs were due to biogenic and traffic emissions. Isoprene, monoterpenes, and several oxygenated VOCs (oVOCs) originated mainly from vegetation either directly or as oxidation products. Isoprene average concentrations in Patras and Athens were 1 and $0.7 \mathrm{ppb}$ respectively, while the monoterpene concentrations were 0.3 and $0.9 \mathrm{ppb}$ respectively. Traffic was the main source of aromatic compounds during summer. For Patras and Athens the average concentrations of benzene were 0.1 and $0.2 \mathrm{ppb}$, of toluene 0.3 and $0.8 \mathrm{ppb}$, and of the xylenes 0.3 and $0.7 \mathrm{ppb}$ respectively.

Winter measurements in Athens revealed that biomass burning used for residential heating was a major VOC source contributing both aromatic VOCs and biogenic compounds such as monoterpenes. Several episodes related to biomass burning were identified and emission ratios (ERs) and emission factors (EFs) were estimated.
\end{abstract}

\section{Introduction}

VOCs play an important role in atmospheric chemistry. Their reactions with hydroxyl $(\mathrm{OH})$ radicals, ozone $\left(\mathrm{O}_{3}\right)$, and nitrate $\left(\mathrm{NO}_{3}\right)$ radicals produce secondary gas- and particulatephase species (Atkinson, 2000; Hallquist et al., 2009). Many of the VOCs present in the atmosphere have adverse effects on human health (Kampa end Castanas, 2008), with exposure to compounds such as benzene, formaldehyde, and acetaldehyde having been related to cancer (Flesca et al., 1999). The European Commission has established an average annual limit of $1.5 \mathrm{ppb}$ for benzene.

VOCs may originate from both natural and anthropogenic sources. Vegetation (Kesselmeier and Staudt, 1999; Goldstein and Galbally, 2007), volcanoes (Tassi et al., 2009, 2013), and marine emissions from the decay of organic matter (Kettle and Adreade, 2000; Meskhidze and Nenes, 2006; Colomb et al., 2008) are some of the natural sources that contribute significantly to the global VOC budget. Anthropogenic emissions originate mainly from the use and production of fossil fuels, industrial processes, and biofuel combustion. Biomass burning also contributes substantially both at the regional and global scales (Crutzen and Andreae, 1990; Karl et al., 2007; Koppmann, 2007).

Online measurement techniques with high resolution can provide valuable information about the sources of atmospheric pollutants (Goldstein and Schade, 2000; Millet et al., 2005; Slowik et al., 2010). The proton transfer reaction mass spectrometer (PTR-MS), developed by Lindinger et al. (1998), can continuously measure the levels of a range of VOCs (DeGouw and Warneke, 2007). 
Several campaigns focusing on VOC levels have been conducted in the Mediterranean Basin. Holzinger et al. (2005) reported secondary production of methanol and acetone in biomass burning plumes over the eastern Mediterranean during the MINOS campaign. PTR-MS measurements during summer in the background site of Finokalia (Crete, Greece) (Salisbury et al., 2003) indicated methanol, acetone, acetonitrile, benzene, and toluene concentrations of 3.3-6.1, $2.9-4.5,0.15-0.44,0.13-0.38$, and $0.04-0.08 \mathrm{ppb}$ respectively. Davison et al. (2009) studied the concentration and fluxes of biogenic VOCs in a Mediterranean ecosystem in western Italy during May-June 2007. Median concentrations of $1.6-3.5 \mathrm{ppb}$ for methanol, $0.4-1.3 \mathrm{ppb}$ for acetaldehyde, $1.0-2.0 \mathrm{ppb}$ for acetone, $0.1-0.14 \mathrm{ppb}$ for isoprene, and $0.2-0.3 \mathrm{ppb}$ for the monoterpenes were reported. Seco et al. (2011) compared the summer and winter VOC concentrations in a forest site $50 \mathrm{~km}$ away from Barcelona. Aromatic VOCs showed small variations between the two periods, while biogenic VOCs (bVOCs) and oxygenated VOCs (oVOCs) were elevated during summer, mainly due to higher physiological activity and faster photochemistry.

In addition, real-time measurements have been reported for urban or semi-urban environments in the Mediterranean. Filella and Penuelas (2006) studied the sources and variations of VOCs by PTR-MS at a semi-urban site in Barcelona. Aromatic species such as toluene and benzene had diurnal patterns typical of traffic intensity. Their concentrations were higher during December and March. Biogenic species such as isoprene and monoterpenes had variable diurnal profiles during the four measurement periods. The isoprene diurnal cycle suggested considerable contribution from anthropogenic sources. Monoterpenes had higher concentrations at night, decreasing in the morning until midday and increasing again in the evening. For some periods a peak also occurred during morning hours (06:00-09:00 LT), which was attributed to temperature-dependent emissions. Methanol, acetone, and acetaldehyde levels were influenced by biogenic sources during summer. In a study at two sites in the city of Athens, Rappenglück et al. (1998) monitored VOCs continuously over a 30-day late-summer period in 1994 by gas chromatography (GC). The $\mathrm{C}_{4}-\mathrm{C}_{12}$ hydrocarbons measured were strongly related to traffic emissions.

Source apportionment analysis has been applied to VOC datasets in order to quantify the contributions of the different VOC sources (Millet et al., 2005; Brown et al., 2007; Vlasenko et al., 2009; Yuan et al., 2012). Slowik et al. (2010) performed PMF analysis of a PTR-MS dataset as well as a unified AMS/PTR-MS dataset over a 2-week period in Toronto Canada. PTR-MS data included 10 mass-to-charge ratios $(\mathrm{m} / \mathrm{z})$. Factors related to traffic, long-range transport, local oxidation, and other sources were reported. Crippa et al. (2013) also performed PMF analysis on an AMS/PTR-MS unified dataset for the city of Paris during the MEGAPOLI project (summer 2009 and winter 2010 campaigns). The resulting common factors associated a large percentage of the aromatic VOCs with the hydrocarbon-like organic aerosol (HOA) during summer, while isoprene and the monoterpenes were mainly related to the semi-volatile oxygenated organic aerosol (SV-OOA). For the winter period wood burning also contributed to the levels of the above species. Yuan et al. (2012) reported that reactions interfere with the PMF analysis of VOCs, proposing that one source can yield several factors at different stages of photochemical processing.

Despite the previous efforts, little is known concerning the current VOC sources in urban areas of the eastern Mediterranean. Elevated PM concentrations have been detected in many urban areas (Pikridas et al., 2013), but the corresponding VOC emission and concentrations have not been quantified. Enhanced sunlight intensity, higher temperature, and $\mathrm{O}_{3}$ concentrations during summer promote the emissions and oxidation of several VOCs. The aim of this work is to provide insights about the current VOC composition and origin in urban areas in the eastern Mediterranean during summer and winter. Another objective of the present study is to assess the impact of residential biomass burning for wintertime VOC levels in these urban areas.

\section{Experimental}

\subsection{Sampling sites}

Summer measurements in Patras (population $~ 300000$ ) were conducted during 11-26 June 2012 in the Institute of Chemical Engineering Sciences (ICE-HT), located $8 \mathrm{~km}$ northeast of the city center (lat $38.298^{\circ}$, long $21.809^{\circ}$, elevation $100 \mathrm{~m}$ ). The area is surrounded by low vegetation and olive tree fields. The Athens (population $\sim 4$ million) summer campaign was conducted between 3 and 26 July 2012 at the Demokritos National Center for Scientific Research in Athens (N.C.S.R.), which is located $8 \mathrm{~km}$ from the city center (lat $37.995^{\circ}$, long $23.816^{\circ}$, elevation $280 \mathrm{~m}$ ) at the foothills of a mountain covered with pine vegetation. For the Athens winter campaign, the National Observatory of Athens (N.O.A.) (lat $37.973^{\circ}$, long $23.718^{\circ}$, elevation $110 \mathrm{~m}$ ) was selected due to its proximity to the city center $(<1.5 \mathrm{~km})$. The selected urban site is located on top of a small hill away from major city roads. The Athens winter campaign took place from 9 January to 6 February 2013. The locations of all sampling sites are presented in Fig. 1.

\subsection{Experimental setup}

Patras summer campaign. VOC concentrations were monitored by a PTR-MS (PTR-QMS 500, Ionicon Analytik). A high-resolution time-of-flight aerosol mass spectrometer (HR-ToF-AMS, Aerodyne Research) was used for the characterization of the aerosol composition. A multi-angle absorption photometer (MAAP 5012, Thermo Scientific) monitored the black carbon (BC) concentration. A series of commercially available gas monitors was used for measuring ni- 


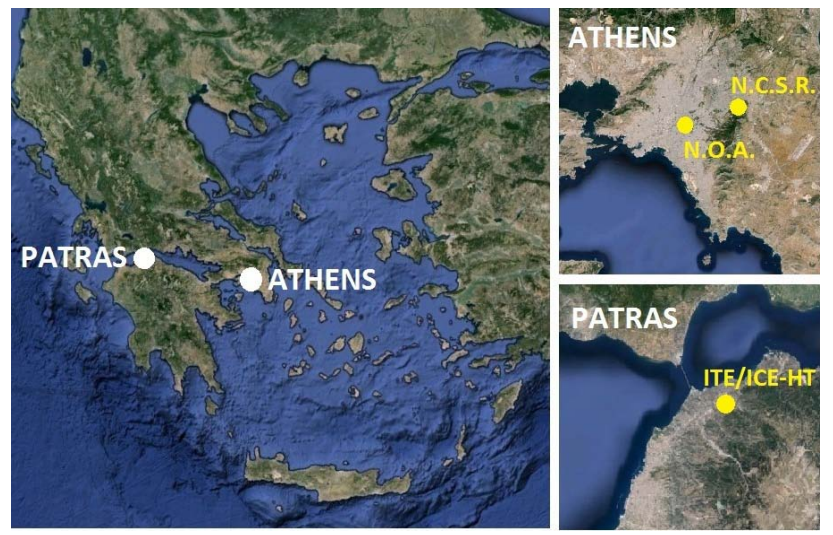

Figure 1. Maps of Greece, Athens, and Patras together with the locations of the measurement sites used during the three campaigns.

trogen oxides $\left(\mathrm{NO}_{x}\right), \mathrm{O}_{3}$, and sulfur dioxide $\left(\mathrm{SO}_{2}\right)$ (API Teledyne, models T201, 400E, and 100EU respectively). The $\mathrm{NO}_{x}$ monitor uses a molybdenum oxide catalyst and chemiluminescence and its measurements are known to be subject to interferences by gas-phase nitric acid, alkyl nitrates, etc. (Dunlea et al., 2007). A scanning mobility particle sizer (SMPS) provided the number size distributions (TSI, models 3080 and 3787). Meteorological variables and sunlight intensity were also measured. The sampling was conducted at approximately $15 \mathrm{~m}$ above ground. All gas species were sampled through Teflon (PTFE) tubing, while all particulate species were sampled through $3 / 8$ in. copper tubing.

Athens summer campaign. The same instrumentation (PTR-MS and HR-ToF-AMS) was used for the Athens summer campaign. BC concentration was provided by an Aethalometer operating at $880 \mathrm{~nm}$ (Magee Scientific, AE31). An SMPS measured the particulate number distributions (model 3022 TSI, custom DMA). A $\mathrm{PM}_{2.5}$ cyclone and a silica dryer were installed prior to the SMPS and the Aethalometer. The PTR-MS and AMS were measuring from inside the mobile laboratory of the Laboratory of Air Quality Studies (LAQS) parked next the N.C.S.R. station. Sampling for these instruments was conducted at $6 \mathrm{~m}$ above ground. For the PTR-MS sampling $1 / 4$ in. PTFE tubing was used. For the AMS $3 / 8 \mathrm{in}$. copper tubing was selected. $\mathrm{O}_{3}$ and $\mathrm{NO}_{x}$ concentrations were measured by the Ministry of Environment, Energy and Climate Change at an adjacent (300 m away) station.

Athens winter campaign. The instrumentation used was the same as in the Patras summer campaign. Additionally, carbon monoxide $(\mathrm{CO})$ and carbon dioxide $\left(\mathrm{CO}_{2}\right)$ were monitored (API Teledyne, models $300 \mathrm{E}$ and T360 respectively). A Horiba monitor (model APSA 365) was used for the $\mathrm{SO}_{2}$ measurements. Meteorological data were obtained by the National Observatory of Athens. All sampling inlets were approximately $6 \mathrm{~m}$ above ground.
PTR-MS operation. In all three campaigns, $\mathrm{H}_{3} \mathrm{O}^{+}$was used as the reaction reagent for the PTR-MS. The drift tube was operated at a pressure of $2.2-2.3$ mbar and its voltage was $600 \mathrm{~V}$. The inlet flow was $0.5 \mathrm{~L} \mathrm{~min}^{-1}$ and the inlet tube and reaction chamber were heated to $60^{\circ} \mathrm{C}$. The residence time in the sampling lines prior to the PTR-MS was $10 \mathrm{~s}$ for the Patras summer campaign, $12 \mathrm{~s}$ for the Athens summer campaign, and $16 \mathrm{~s}$ for the Athens winter campaign. The corresponding ratio of the electric field strength to the gas number density was approximately $126 \mathrm{Td}\left(1 \mathrm{Td}=10^{-17} \mathrm{~V} \mathrm{~cm}^{2}\right)$. Blanks were obtained at regular intervals through an activated carbon filter (Supelpure HC, Supelco). A Teflon filter was installed before the sampling inlet. Concentrations were monitored in the multiple ion detection (MID) mode with a total cycle time of $10 \mathrm{~s}$. The dwell times were in the range of $5-500 \mathrm{~ms}$. A $200 \mathrm{~ms}$ dwell time was used for most of the reported $m / z$ values. For some of the higher $m / z$ values a dwell time of $500 \mathrm{~ms}$ was selected. The dwell times for $\mathrm{m} / z 21,30$, 32 , and 37 were $200,5,5$, and $10 \mathrm{~ms}$ respectively in all three campaigns.

Calibrations were performed once per week. The sensitivities for the reported compounds for all campaigns were in the range of 4.7 to $24 \mathrm{ncpsppb}^{-1}$. These values did not change significantly (less than $40 \%$ ) during the three deployments. The detection limits for the calibrated compounds based on Karl et al. (2003) were in the range of 34 to 97 ppt. Humidity effects on the sensitivities of the individual compounds were not considered during the calibrations. A precision calibrator (Teledyne, model 702) was used for the dilution of the VOC standard with VOC-free air (using a Supelco filter). This calibrator type does not substantially change the $\mathrm{RH}$ of the air. The ratio of $m / z 37$ to $m / z 19$ was $0.039 \pm 0.009$ during the Patras summer campaign, $0.044 \pm 0.012$ during the Athens summer campaign, and $0.038 \pm 0.008$ during the Athens winter campaign. In all campaigns the $m / z 37$ to $m / z 19$ ratio was always less than 0.06 (typically ranging from 0.025 to 0.05 ). This ratio is considered low and stable; thus, no corrections were applied for the $\mathrm{H}_{3} \mathrm{O}^{+}\left(\mathrm{H}_{2} \mathrm{O}\right)$ ion. The concentrations of all compounds were normalized to the primary hydronium ion signal. For compounds for which calibration was not possible, the corresponding mixing ratios were estimated based on Eq. (3) of Taipale et al. (2008). Concentrations are calculated based on

$[\mathrm{VOC}]=\mathrm{CF} \mathrm{RH}{ }^{+} / \mathrm{H}_{3} \mathrm{O}^{+}$,

where $\mathrm{CF}$ is the calibration factor for each VOC and $\mathrm{RH}^{+}$ and $\mathrm{H}_{3} \mathrm{O}^{+}$are the counts per second for the corresponding VOC and the primary ion respectively. The concentrations reported for the non calibrated $m / z$ 's are calculated for a reaction rate of

$k=2.0 \times 10^{-9} \mathrm{~cm}^{3} \mathrm{~s}^{-1}$.

Table S1 in the Supplement summarizes the VOCs measured during the three campaigns. Formaldehyde $(\mathrm{m} / z 31)$ 
was not included in this dataset due to issues related to the humidity dependence of the measurements and its low proton affinity (DeGouw and Warneke, 2007). Methanol was also excluded due to the difficulty of obtaining methanolfree air for the background measurements with the activated carbon filter. Acetaldehyde $(m / z 45)$ was also excluded from the dataset due to negative values, probably resulting from $\mathrm{CO}_{2}$ interferences (DeGouw and Warneke, 2007). Finally, acrolein $(m / z 57)$ and $m / z 41$ were not included due to spikes associated with butanol emissions from the SMPS instruments. Details for the rest of the instrumentation used in the campaigns can be found elsewhere (Kostenidou et al., 2015; Florou et al., 2016).

\subsection{PMF analysis}

The PMF technique (Paatero and Tapper, 1994; Lanz et al., 2007) was used for the deconvolution of the PTR-MS data into factors. The analysis was performed using the PMF evaluation tool (Ulbrich et al., 2009) with Igor Pro 6.22A (Wavemetrics). The uncertainties were calculated based on Poisson ion-counting statistics (DeGouw et al., 2003) and the measured background concentrations. The overall uncertainty is described by (DeGouw et al., 2003; Slowik et al., 2010)

$\Delta\left(I-I_{\mathrm{b}}\right)=\sqrt{\frac{I}{\tau}+\frac{I_{\mathrm{b}}}{\tau_{\mathrm{b}}}}$,

where $I$ is the signal of the main measurements, $I_{\mathrm{b}}$ is the signal from the background measurements, $\Delta\left(I-I_{\mathrm{b}}\right)$ is the overall uncertainty, $\tau$ is the dwell time of the main sampling, and $\tau_{\mathrm{b}}$ is the dwell time of the background sampling. A total of $29 \mathrm{~m} / z$ values (Table S1) were used for the PMF analysis. Mixing ratios (ppb) were used as input for the PMF model. Solutions with up to 10 factors were examined with an $f_{\text {peak }}$ ranging from -2.0 to 2.0 with a step of 0.2 . The averaging time used was $5 \mathrm{~min}$. The optimum solution for each measurement period was selected by evaluation of the model residuals, the mass spectra composition, and the correlations of the factor time series with other measured pollutants. The estimated concentrations by the PMF correlated very well ( $R^{2}$ ranged from 0.994 to 0.999 , Fig. S47) with the measured values for all three campaigns.

\section{VOC concentrations and diurnal profiles}

\subsection{Patras summer 2012}

The overall measurement period can be divided into three sub-periods based on the prevailing meteorology, namely 1115, 16-22, and 23-26 June. During the first period SW winds prevailed with an average temperature of $24.4^{\circ} \mathrm{C}$, a wind speed of $3 \mathrm{~m} \mathrm{~s}^{-1}$, and $58 \%$ relative humidity. The second period was characterized by higher temperatures $\left(28.4^{\circ} \mathrm{C}\right)$ and stronger $\left(5.3 \mathrm{~m} \mathrm{~s}^{-1}\right)$ E-NE winds. The average relative humidity was $29 \%$. The final period had SW winds mainly during the day and E-NE winds during the night. The average temperature was $27.2^{\circ} \mathrm{C}$ and the average relative humidity was $49 \%$. Average wind speed decreased during this period to $2.4 \mathrm{~m} \mathrm{~s}^{-1}$. There was no precipitation during the campaign. Additional information about the meteorological conditions and solar radiation can be found in the Supplement (Fig. S1). Back-trajectory FLEXPART (Stohl et al., 2005) and HYSPLIT analysis (Draxler and Rolph, 2013) was performed (Kostenidou et al., 2015). The air masses were influenced mostly by the marine environment during the first period and by continental Greece during the second and third period.

Table 1 summarizes the average, median, and upper and lower quartile of the concentrations for the some of the VOCs along with other gas and particulate species. Acetone was the most abundant VOC with an average concentration of $2.9 \mathrm{ppb}$. Acetic acid had a mean concentration of $2.2 \mathrm{ppb}$. The $m / z 69$, reported here as isoprene, had an average concentration of $1 \mathrm{ppb}$. Throughout the campaign, the acetonitrile levels were on average $0.1 \mathrm{ppb}$ with a flat diurnal profile, suggesting that biomass burning was not an important VOC source. Time series for the reported VOCs are presented in the Supplement (Fig. S2). Maximum values for the aromatic compounds were in the range of $1 \mathrm{ppb}$ for toluene and the xylenes, while benzene concentrations of up to $0.4 \mathrm{ppb}$ were measured. Isoprene and the monoterpenes had peak concentrations up to 3 and $1 \mathrm{ppb}$ respectively at noon.

The average diurnal profiles for some of the VOCs measured are shown in Fig. 2. The concentrations of isoprene, the monoterpenes, methyl vinyl ketone (MVK), and methacrolein (MACR) were low during nighttime (Fig. 2ac) and increased in the afternoon with a maximum at 15:0016:00 LT. Other compounds of mainly biogenic origin such as methyl ethyl ketone (MEK) (Fig. 2d) displayed a similar diurnal pattern, having two additional small peaks at 09:00 and 22:00 LT, something that shows either the influence of anthropogenic sources or the contribution of other molecules to the $m / z 73$ signal, reported here as MEK. Most of the biogenic VOCs had higher concentrations during the second and third period. During these periods the air masses reaching the site passed over continental Greece, where there are mountains with forests.

Aromatic VOCs, like benzene, toluene, and xylenes, displayed diurnal cycles (Fig. 2e, f, g) characteristic of traffic emissions, with a peak during the morning rush hour at 08:00 LT and one peak in the evening at 22:00 LT. This evening peak can be justified by the local lifestyle, especially the closing of the market at 21:00. Higher concentrations were observed during the first period and during daytime for the third period (Fig. S2). This is consistent with significant local aromatic sources. The toluene to benzene ratio for the overall period was 2.5. During the three periods, the toluene to benzene ratio was 2.3, 2.0, and 2.6 respectively. Most of the reported toluene to benzene ratios in the literature are 
Table 1. Concentrations ( 5 min averages) of VOCs and other pollutants during the Patras summer campaign.

\begin{tabular}{lrrrrr}
\hline & & $\begin{array}{c}\text { Lower } \\
\text { quartile }\end{array}$ & Median & Average & $\begin{array}{r}\text { Upper } \\
\text { quartile }\end{array}$ \\
\cline { 3 - 6 } VOCs & $m / z$ & & Concentration $(\mathrm{ppb})$ & \\
\hline Acetonitrile & 42 & 0.08 & 0.10 & 0.12 & 0.14 \\
Formic acid, ethanol & 47 & 0.40 & 0.86 & 0.89 & 1.35 \\
Acetone & 59 & 2.05 & 2.44 & 2.93 & 3.23 \\
Acetic acid & 61 & 1.16 & 1.88 & 2.15 & 2.90 \\
Isoprene & 69 & 0.32 & 0.85 & 1.01 & 1.46 \\
MVK+ MACR & 71 & 0.16 & 0.24 & 0.30 & 0.38 \\
MEK & 73 & 0.18 & 0.25 & 0.30 & 0.42 \\
Benzene & 79 & 0.06 & 0.09 & 0.12 & 0.17 \\
Toluene & 93 & 0.10 & 0.19 & 0.28 & 0.43 \\
Xylenes & 107 & 0.09 & 0.15 & 0.25 & 0.37 \\
Monoterpenes & 137 & 0.09 & 0.19 & 0.33 & 0.50 \\
\hline Other species & $\mathrm{Units}$ & & & & \\
\hline Black carbon $\left(\mathrm{BC}^{2}\right)$ & $\mu \mathrm{g} \mathrm{m}^{-3}$ & 0.27 & 0.44 & 0.49 & 0.67 \\
Sulfur dioxide $\left(\mathrm{SO}_{2}\right)$ & $\mathrm{ppb}$ & 0.98 & 1.15 & 1.25 & 1.41 \\
Nitrogen oxides $\left(\mathrm{NO}_{x}\right)$ & $\mathrm{ppb}$ & 1.8 & 3.7 & 5.1 & 6.4 \\
Ozone $\left(\mathrm{O}_{3}\right)$ & $\mathrm{ppb}$ & 41.2 & 49.2 & 48.7 & 56.4 \\
\hline
\end{tabular}
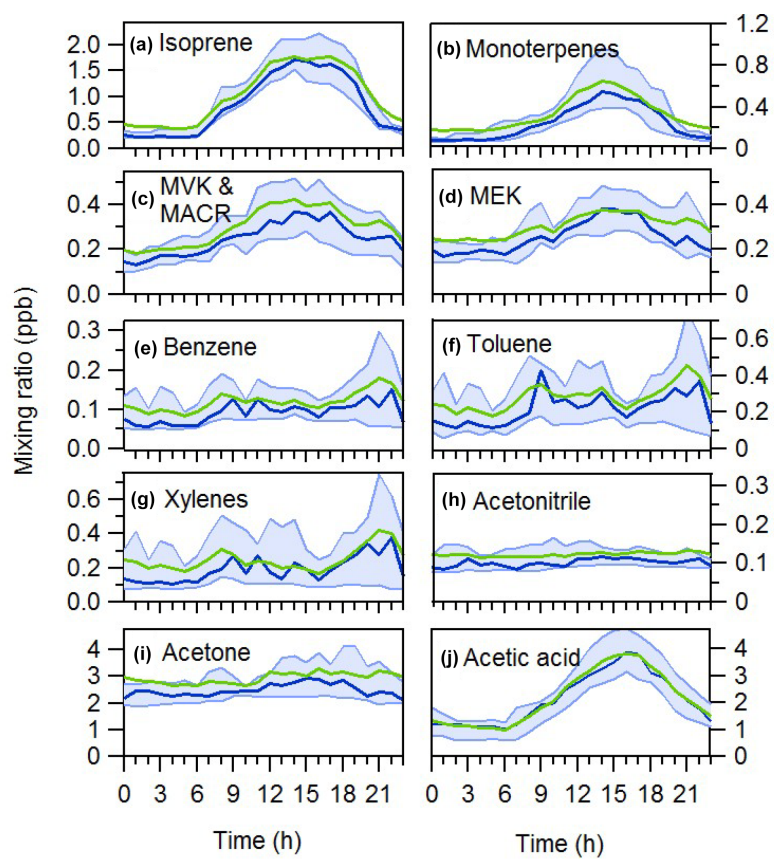

Figure 2. Average VOC diurnal profiles during the Patras summer campaign. Green lines present the average values. The median value is shown with blue. The blue area corresponds to the interquartile range.

in the range of 1 or less (for aged air masses) to 4 (associated with fresh emissions measured in tunnels) (Roberts et al., 1984; Salisbury et al., 2003; Kristensson et al., 2004). Assuming no influence from biomass burning sources (the acetonitrile levels were low), this ratio can be considered as a photochemical clock (Roberts et al., 1984); thus, the sampled air during the second period was on average more aged. During this period the air masses sampled were less influenced by the city of Patras and the surrounding areas.

Acetone's concentrations were marginally elevated during daytime from 13:00 to 22:00 LT (Fig. 2i). Several oVOCs had a diurnal pattern similar to the biogenic VOCs. The diurnal profile of acetic acid (Fig. $2 \mathrm{j}$ ) peaked at approximately 17:00 LT. Higher values of the oVOCs were observed during the second period (Supplement Sect. S2, Fig. S2), suggesting strong biogenic influence.

$\mathrm{NO}_{x}$ and $\mathrm{BC}$ concentrations displayed diurnal profiles (Figs. S3 and S4) similar to those of the aromatic species, typical of traffic emissions. Higher values were observed for both species during the first and third periods, while for the second period lower values were measured due to the strong E-NE winds. The average concentration for $\mathrm{NO}_{x}$ was $5.1 \mathrm{ppb}$, while for $\mathrm{BC}$ a mean value of $0.5 \mu \mathrm{g} \mathrm{m}^{-3}$ was measured. $\mathrm{SO}_{2}$ concentrations were elevated during the day. A peak during morning rush hour, similar to the aromatic VOCs, was observed but no peak was evident during evening rush hour. This can be explained by the low activity of heavy trucks during these hours (22:00-23:00 LT). A mean value of $1.3 \mathrm{ppb}$ was found for $\mathrm{SO}_{2}$. Ozone concentrations were elevated during the second period exceeding $60 \mathrm{ppb}(8 \mathrm{~h}$ average) during the night of 17 to 18 July. These elevated $\mathrm{O}_{3}$ levels were the result of long-range transport from continental Greece and the Balkans. The importance of the long-range transport can be seen in Fig. S3, showing the ozone concentrations during this windy period. The maximum ozone 
concentration was actually observed a little before the midnight of 18 June. This was actually the highest ozone level during the measurement period. This was in contrast to the low levels of $\mathrm{NO}_{x}$ and $\mathrm{BC}$ observed during the same period. These results shown in Fig. S3 strongly support the conclusion that the high levels of ozone were due to longrange transport. Similar conclusions have been reached by Kouvarakis et al. (2002), reporting measurements performed onboard a cruise ship traveling on a regular basis in the area. They concluded that long-range transport is the main factor contributing to high ozone levels in eastern Greece. During these two days an average value of $55 \mathrm{ppb}$ was measured. Diurnally averaged $\mathrm{O}_{3}$ concentrations for the overall measurement period started to increase at 09:00 LT, with a maximum of $58 \mathrm{ppb}$ during 15:00-16:00 LT. During the night (21:0007:00 LT) $\mathrm{O}_{3}$ concentrations were in the range of $45 \mathrm{ppb}$.

\subsection{Athens summer 2012}

The Athens summer campaign was characterized by a prolonged heat wave with temperatures reaching up to $40^{\circ} \mathrm{C}$. The average temperature was $29.6^{\circ} \mathrm{C}$ and the corresponding relative humidity was $40 \%$. Local topography dictated the wind patterns, with the wind having mainly an E-SE direction. The wind direction varied especially during the morning hours (08:00-11:00 LT) with wind shifts bringing air masses from the $\mathrm{N}$ or $\mathrm{E}$ of the site. The average wind speed was $1.7 \mathrm{~m} \mathrm{~s}^{-1}$ with very low values during the night. No precipitation occurred throughout the campaign. More information concerning the meteorological conditions is included in the Supplement (Fig. S5).

Acetone was the most abundant VOC with an average value of $4.3 \mathrm{ppb}$ (Table 2), significantly higher than in $\mathrm{Pa}-$ tras. Throughout the campaign the acetonitrile concentrations were on average $0.2 \mathrm{ppb}$ with a flat diurnal profile, suggesting the lack of biomass burning sources. Figure S6 includes all the VOC time series for the Athens summer campaign. Toluene and the xylenes peaked during the morning hours at concentrations in the range of $3 \mathrm{ppb}$, while benzene had typical maximum values around $1 \mathrm{ppb}$ during these hours. Isoprene and the monoterpenes peaked at noon with concentrations in the range of 1 and 2 ppb respectively.

The average isoprene concentration was $0.7 \mathrm{ppb}$ with a diurnal profile (Fig. 3a) similar to Patras. Local sources significantly influenced the monoterpene concentrations (Fig. 3b) with a peak during the morning hours (from 06:30 to 08:30) followed by several hours of elevated levels with a maximum at approximately 15:00-16:00 LT. This behavior is similar to that reported by Filella and Penuelas (2006) for the Barcelona semi-urban site. Nighttime stagnation conditions followed by morning $\mathrm{N}$ or $\mathrm{NE}$ winds caused these elevated concentrations by transporting to the site nighttime emissions from the adjacent pine forest. MVK and MACR (Fig. 3c) had a similar diurnal cycle to that of isoprene, while MEK

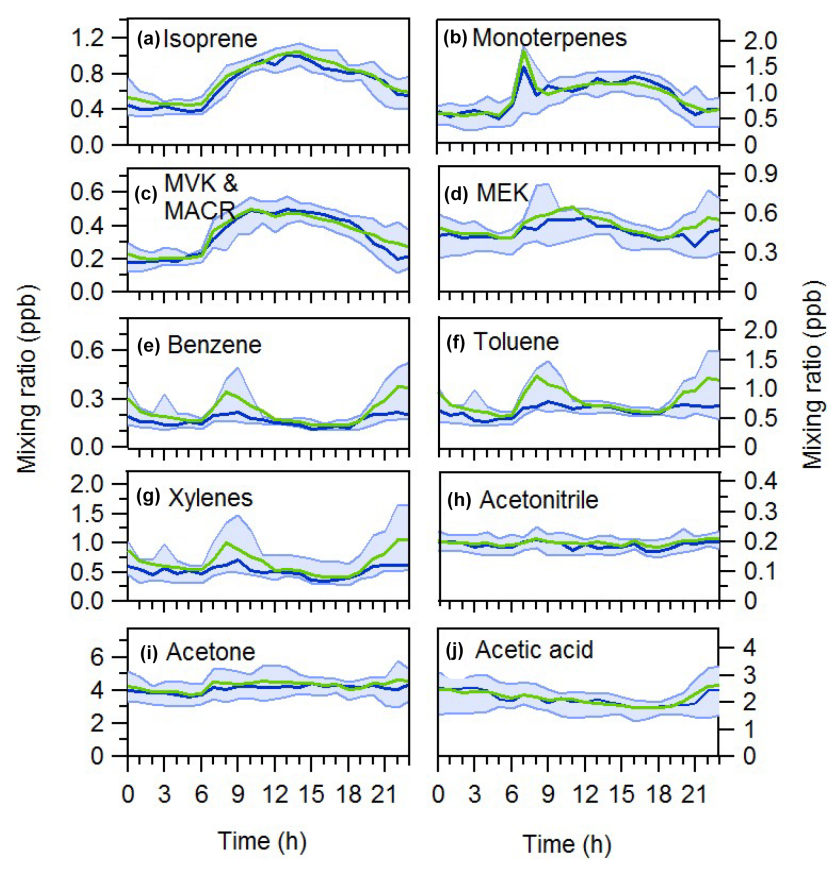

Figure 3. Average VOC diurnal profiles during the Athens summer campaign. Green lines present the average values. The median value is shown with blue. The blue area corresponds to the interquartile range.

(Fig. 3d) peaked at 11:00-12:00 LT and had one more peak at 22:00, something also seen in the Patras summer campaign.

In Athens, higher aromatic concentrations were observed compared to the Patras summer campaign. These species had similar diurnal cycles (Fig. 3e, f, g) characteristic of traffic emissions, with a peak during the morning rush hour at 08:00-09:00 LT and one wide peak during the evening from 19:30 to 01:00 LT. The toluene to benzene ratio for the Athens summer campaign was 3.4, a value similar to that of fresh traffic emissions (Kristensson et al., 2004). Rappenglück et al. (1998) reported a toluene to benzene ratio of 2.3 for the Demokritos site during August-September 1994. The correlation coefficients between the aromatic species (benzene, toluene, xylenes, $\mathrm{C}_{9}$ and $\mathrm{C}_{10}$ aromatics) were high ( $R^{2}$ ranging from 0.92 to 0.96 ), suggesting a single source related to traffic emissions.

The diurnal profiles of most oVOCs suggest anthropogenic influence (Fig. 3i and j). Acetone concentrations were elevated during the day with additional peaks during morning rush hour and during night (24:00 LT). Acetic acid concentrations were lower during the day with a peak at 22:0023:00 LT and elevated concentrations during night hours. Morning rush hour had a very small effect on acetic acid's levels. This compound appears to be associated mainly with regional sources.

The measured concentrations of acetonitrile, acetone, benzene, and toluene in Patras and Athens were lower than sum- 
Table 2. Concentrations ( 5 min averages) of VOCs and other pollutants during the Athens summer campaign.

\begin{tabular}{lrrrrr}
\hline & & $\begin{array}{c}\text { Lower } \\
\text { quartile }\end{array}$ & Median & Average & $\begin{array}{r}\text { Upper } \\
\text { quartile }\end{array}$ \\
\cline { 3 - 6 } VOCs & $m / z$ & & Concentration $(\mathrm{ppb})$ & \\
\hline Acetonitrile & 42 & 0.16 & 0.19 & 0.20 & 0.23 \\
Formic acid, ethanol & 47 & 1.12 & 1.51 & 1.52 & 1.87 \\
Acetone & 59 & 3.27 & 4.09 & 4.28 & 4.92 \\
Acetic acid & 61 & 1.53 & 2.04 & 2.17 & 2.65 \\
Isoprene & 69 & 0.46 & 0.72 & 0.73 & 0.93 \\
MVK + MACR & 71 & 0.20 & 0.32 & 0.35 & 0.47 \\
MEK & 73 & 0.32 & 0.45 & 0.50 & 0.59 \\
Benzene & 79 & 0.12 & 0.16 & 0.22 & 0.24 \\
Toluene & 93 & 0.48 & 0.62 & 0.81 & 0.82 \\
Xylenes & 107 & 0.35 & 0.51 & 0.67 & 0.77 \\
Monoterpenes & 137 & 0.54 & 0.88 & 0.92 & 1.22 \\
\hline Other species & $\mathrm{Units}^{2}$ & & & & \\
\hline Black carbon $(\mathrm{BC})$ & $\mu \mathrm{g} \mathrm{m}{ }^{-3}$ & 0.43 & 0.60 & 0.72 & 0.89 \\
Nitrogen oxides $\left(\mathrm{NO}_{x}\right)$ & $\mathrm{ppb}$ & 5.1 & 5.6 & 7.3 & 7.5 \\
Ozone $\left(\mathrm{O}_{3}\right)$ & $\mathrm{ppb}$ & 49.6 & 55.5 & 54.1 & 59.1 \\
\hline
\end{tabular}

mer measurements from Paris, Beijing, Mexico City, Tokyo, Houston, London, and Mohali (Sinha et al., 2014). Isoprene concentrations though were comparable with the findings from the above cities.

$\mathrm{NO}_{x}$ and $\mathrm{BC}$ concentrations displayed diurnal profiles similar to those of the aromatic species, typical of traffic emissions (Figs. S7 and S8). The average concentration of $\mathrm{NO}_{x}$ was $7.3 \mathrm{ppb}$, while $\mathrm{BC}$ had an average value of $0.7 \mu \mathrm{g} \mathrm{m}^{-3}$. Increased solar radiation along with the availability of $\mathrm{O}_{3}$ precursors resulted in high $\mathrm{O}_{3}$ exceeding the EU $60 \mathrm{ppb} 8 \mathrm{~h}$ limit in 4 days during the 13-day period. The $\mathrm{O}_{3}$ average diurnal pattern was similar to that of Patras during the summer with a maximum of $60 \mathrm{ppb}$ during 15:0016:00 LT. During the night concentrations of $50 \mathrm{ppb}$ were measured.

\subsection{Athens winter 2013}

Due to the recent economic crisis and the increasing prices of heating oil at the time, a significant percentage of the population in Greece has been using wood for residential heating during the winter. During the winter of 2012-2013, extreme episodes of atmospheric pollution occurred in Athens, with hourly $\mathrm{PM}_{1}$ levels reaching values up to $140 \mu \mathrm{g} \mathrm{m}^{-3}$ (Florou et al., 2016). The average temperature, humidity, and wind speed during the Athens winter campaign were $11.9^{\circ} \mathrm{C}$, $70 \%$, and $3.4 \mathrm{~m} \mathrm{~s}^{-1}$ respectively. The wind direction patterns favored mainly S-SW winds and occasionally N-NE winds. Minimum night temperatures ranged from 3.3 to $15^{\circ} \mathrm{C}$. Precipitation occurred during 11, 16, 18, 24, 25, and 26 January. Meteorological data are included in the Supplement (Figs. S9 and S10).
Table 3 summarizes the average, median, and lower and upper quartiles of the concentrations for some of the measured VOCs. The substantial difference between the median and average values for most species is due to periods with significant residential wood burning and correspondingly high concentrations. Concentrations of acetone and acetic acid reached $15 \mathrm{ppb}$, while isoprene levels were as high as 9 ppb. Acetone, acetic acid, and toluene had mixing ratios with median values in the range of $1.5 \mathrm{ppb}$. Acetone levels were significantly lower compared to the summer campaign. Formic acid/ethanol and acetic acid had concentrations similar to the summer. The time series of the measured VOCs is shown in Fig. S11 in the Supplement.

Most of the VOCs (Fig. 4) had higher average concentrations during the night and during the morning rush hour (peak at 09:00 LT). Evening concentrations started to increase at 19:00 LT. Very high concentration periods were detected for most of the measured VOCs. Aromatics increased during the morning rush hour together with formic acid and acetone. The toluene to benzene ratio for the campaign was 2.1, suggesting the importance of other sources in contrast to the summer ratio (3.4) when traffic dominated.

Isoprene and the monoterpenes had elevated concentrations during the morning but also during the evening (18:0023:00 LT) (Fig. 4a and b), mainly due to biomass burning. MVK, MACR, and MEK were also produced by biomass burning sources (Fig. $4 \mathrm{c}$ and d). Although these compounds dominate their specific $m / z$ values $(m / z: 69,71,73)$ in typical rural environments, other compounds may be present in these $m / z$ values during the Athens winter campaign. Karl et al. (2007) reported furan and other alkenes being detected at $m / z 69$, crotonaldehyde and other alkenes for $m / z 71$, and 
Table 3. Concentrations ( $5 \mathrm{~min}$ averages) of VOCs and other pollutants during the Athens winter campaign. Values are shown for the overall period and for the biomass burning periods.

\begin{tabular}{|c|c|c|c|c|c|c|c|c|c|}
\hline & & \multicolumn{4}{|c|}{ Overall measurement period } & \multicolumn{4}{|c|}{ Biomass burning periods } \\
\hline & & $\begin{array}{l}\text { Lower } \\
\text { quartile }\end{array}$ & Median & Average & $\begin{array}{r}\text { Upper } \\
\text { quartile }\end{array}$ & $\begin{array}{l}\text { Lower } \\
\text { quartile }\end{array}$ & Median & Average & $\begin{array}{r}\text { Upper } \\
\text { quartile }\end{array}$ \\
\hline VOCs & $m / z$ & \multicolumn{8}{|c|}{ Concentration (ppb) } \\
\hline Acetonitrile & 42 & 0.05 & 0.08 & 0.16 & 0.18 & 0.34 & 0.45 & 0.55 & 2.70 \\
\hline Formic acid, ethanol & 47 & 0.95 & 1.33 & 1.80 & 2.01 & 2.31 & 3.13 & 3.69 & 4.57 \\
\hline Acetone & 59 & 1.10 & 1.52 & 2.24 & 2.48 & 4.05 & 5.04 & 5.76 & 6.74 \\
\hline Acetic acid & 61 & 0.95 & 1.38 & 2.11 & 2.42 & 2.65 & 4.02 & 5.26 & 6.22 \\
\hline Isoprene & 69 & 0.41 & 0.60 & 1.05 & 1.07 & 1.92 & 2.56 & 3.25 & 3.91 \\
\hline MVK + MACR & 71 & 0.13 & 0.21 & 0.41 & 0.43 & 0.79 & 1.05 & 1.35 & 1.58 \\
\hline MEK & 73 & 0.28 & 0.41 & 0.59 & 0.67 & 1.00 & 1.29 & 1.52 & 1.82 \\
\hline Benzene & 79 & 0.29 & 0.55 & 1.00 & 1.10 & 1.94 & 2.58 & 3.18 & 3.70 \\
\hline Toluene & 93 & 0.94 & 1.34 & 2.34 & 2.72 & 4.23 & 5.49 & 6.25 & 7.06 \\
\hline Xylenes & 107 & 0.43 & 0.83 & 1.69 & 1.94 & 3.32 & 4.28 & 5.09 & 5.68 \\
\hline Monoterpenes & 137 & 0.15 & 0.23 & 0.43 & 0.46 & 0.87 & 1.22 & 1.37 & 1.71 \\
\hline Other species & Units & & & & & & & & \\
\hline Black carbon (BC) & $\mu \mathrm{g} \mathrm{m}^{-3}$ & 0.46 & 1.00 & 2.02 & 2.35 & 5.78 & 7.63 & 7.98 & 9.54 \\
\hline Sulfur dioxide $\left(\mathrm{SO}_{2}\right)$ & $\mathrm{ppb}$ & 0.7 & 1.1 & 1.6 & 1.9 & 1.1 & 1.8 & 2.3 & 3.0 \\
\hline Nitrogen oxides $\left(\mathrm{NO}_{x}\right)$ & $\mathrm{ppb}$ & 5.9 & 1.3 & 24.6 & 26.5 & 51.8 & 70.3 & 79.7 & 93.1 \\
\hline Ozone $\left(\mathrm{O}_{3}\right)$ & $\mathrm{ppb}$ & 8.7 & 25.9 & 21.6 & 32.6 & 1.8 & 2.7 & 3.5 & 4.3 \\
\hline Carbon monoxide (CO) & ppm & 0 & 0.1 & 0.3 & 0.4 & 1.0 & 1.2 & 1.4 & 1.7 \\
\hline Carbon dioxide $\left(\mathrm{CO}_{2}\right)$ & ppm & 380 & 388 & 390 & 402 & 420 & 429 & 432 & 441 \\
\hline
\end{tabular}
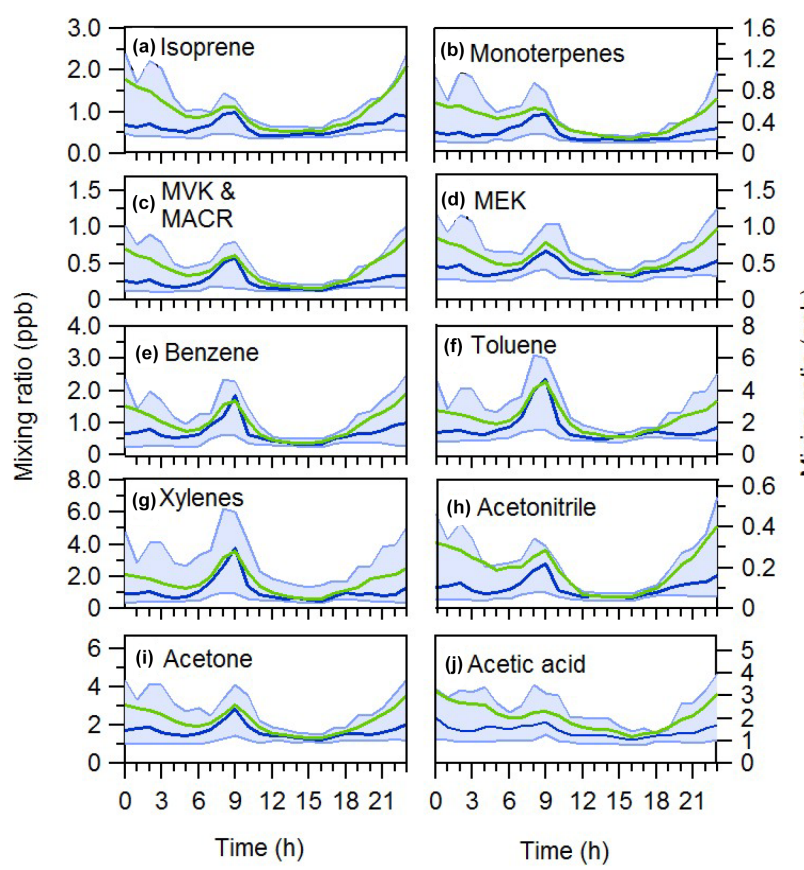

Figure 4. Average VOC diurnal profiles during the Athens winter campaign. Green lines present the average values. The median value is shown with blue. The blue area corresponds to the interquartile range. methyl propanal for $m / z 73$ during the burning of tropical biofuels. Akagi et al. (2011) and Yokelson et al. (2013) reported furan emissions factors higher than isoprene for some biomass fuel types. Based on reported emissions from various biofuel types, furan contributes around $30 \%$ of the $m / z 69$ in most cases (Stockwell et al., 2015; Sarkar et al., 2016). For the Athens winter campaign isoprene is believed to be the major component of $m / z 69$. The VOC concentrations in Athens during winter are lower than those in Kathmandu or Karachi (Sarkar et al., 2016) findings. Acetonitrile, acetone, benzene and toluene levels are similar to those measured in London, Paris, and Barcelona, while the isoprene concentration is higher and closer to the Kathmandu and Karachi values.

$\mathrm{NO}_{x}, \mathrm{BC}$, and $\mathrm{CO}$ had time series and average diurnal profiles (Figs. S12 and S13) that were similar to the majority of the VOCs with peaks at morning rush hour and during the evening (18:00-23:00 LT). Their median values were $11.3 \mathrm{ppb}, 1.0 \mu \mathrm{g} \mathrm{m}^{-3}$, and $100 \mathrm{ppb}$ respectively. $\mathrm{SO}_{2}$ concentrations were elevated mainly during the morning rush hour. During nighttime, lower $\mathrm{SO}_{2}$ values were observed with some peaks around 23:00 LT that can be attributed to traffic and residential heating using diesel fuel. A median value of $1.1 \mathrm{ppb}$ was observed. $\mathrm{O}_{3}$ levels were reduced during the biomass burning periods to almost zero. For periods with stronger winds and low gas and particulate pollutant levels, the $\mathrm{O}_{3}$ concentrations reached 30 to $40 \mathrm{ppb}$. The average $\mathrm{O}_{3}$ 
diurnal pattern had a peak at 15:00 LT and a median value of $25 \mathrm{ppb}$ for the campaign.

Acenonitrile $(m / z 42)$ and levoglucosan's tracer $(m / z 60$ of the AMS) were used as markers in order to identify periods where wood burning had a substantial contribution to the VOC and particulate levels. The concentration of these two species (Sect. S4.1) had a relatively high correlation $\left(R^{2}=0.78\right)$. In both cases elevated concentrations were observed mainly during the night but also during the morning, having a peak at 09:00 LT. These morning peaks can be attributed to residential heating at these hours but can also be a result of vertical mixing of the atmosphere. The acetonitrile's relative increase is higher than that of the levoglucosan tracer (Fig. 5) during the morning rush hour. Recently, Dunne et al. (2012) reported interferences at PTR-MS $m / z 42$ under the $\mathrm{H}_{3} \mathrm{O}^{+}$reaction when measuring in polluted urban environments. These interferences were attributed to the ${ }^{13} \mathrm{C}$ isotopologues of $\mathrm{C}_{3} \mathrm{H}_{5}^{+}$and the product ion $\mathrm{C}_{3} \mathrm{H}_{6}^{+}$formed by reactions with $\mathrm{NO}^{+}$and $\mathrm{O}_{2}^{+}$that exist in trace amounts in the reagent gas $\left(\mathrm{H}_{3} \mathrm{O}^{+}\right)$. This leads to the conclusion that even though an increase due to biomass burning is apparent during the morning hours (increase in levoglucosan's tracer from the AMS), a fraction of $m / z 42$ concentration is due to species other than acetonitrile. During the morning, traffic appears to contribute significantly to the $m / z 42$ increase.

A set of criteria was established in order to select periods during which residential heating dominated the gas and particulate composition of ambient air. These periods (Table S2) occurred during the nighttime (18:00-06:00 LT) and were associated with acetonitrile concentrations exceeding $0.25 \mathrm{ppb}$. During these periods NW winds dominated, bringing air masses from the northern parts of Athens to the site (Fig. S10b). The average concentrations for these periods are shown in Table 3. Excluding the above biomass burning periods from the campaign dataset resulted in a decrease in the average values of the measured species by $11-34 \%$. That is, the average values decreased by $26 \%$ for acetonitrile, $11 \%$ for formic acid and ethanol, $17 \%$ for acetone, $16 \%$ for acetic acid, $23 \%$ for isoprene, $25 \%$ for MVK and MACR, $17 \%$ for MEK, $23 \%$ for benzene, $18 \%$ for toluene, $22 \%$ for the xylenes, and $24 \%$ for the monoterpenes.

\section{Biomass burning emissions}

Emission factors (EFs) were calculated based on

$\mathrm{EF}_{i}=\frac{\left(C_{i}\right)_{\text {plume }}-\left(C_{i}\right)_{\text {back }}}{\left(\mathrm{CO}_{2}\right)_{\text {plume }}-\left(\mathrm{CO}_{2}\right)_{\text {back }}} \mathrm{EF}_{\mathrm{CO}_{2}}$,

where $\left(C_{i}\right)_{\text {plume }}$ and $\left(C_{i}\right)_{\text {back }}$ were the concentrations for species $i$, during the burning and the reference periods (background) respectively and $\left(\mathrm{CO}_{2}\right)_{\text {plume }}$ and $\left(\mathrm{CO}_{2}\right)_{\text {back }}$ are the concentrations of $\mathrm{CO}_{2}$ during the biomass burning and the reference periods. For the $\mathrm{CO}_{2}$ emission factor $\left(\mathrm{EF}_{\mathrm{CO}_{2}}\right)$ a value of $1600 \mathrm{~g} \mathrm{~kg}^{-1}$ was used. This value was selected based
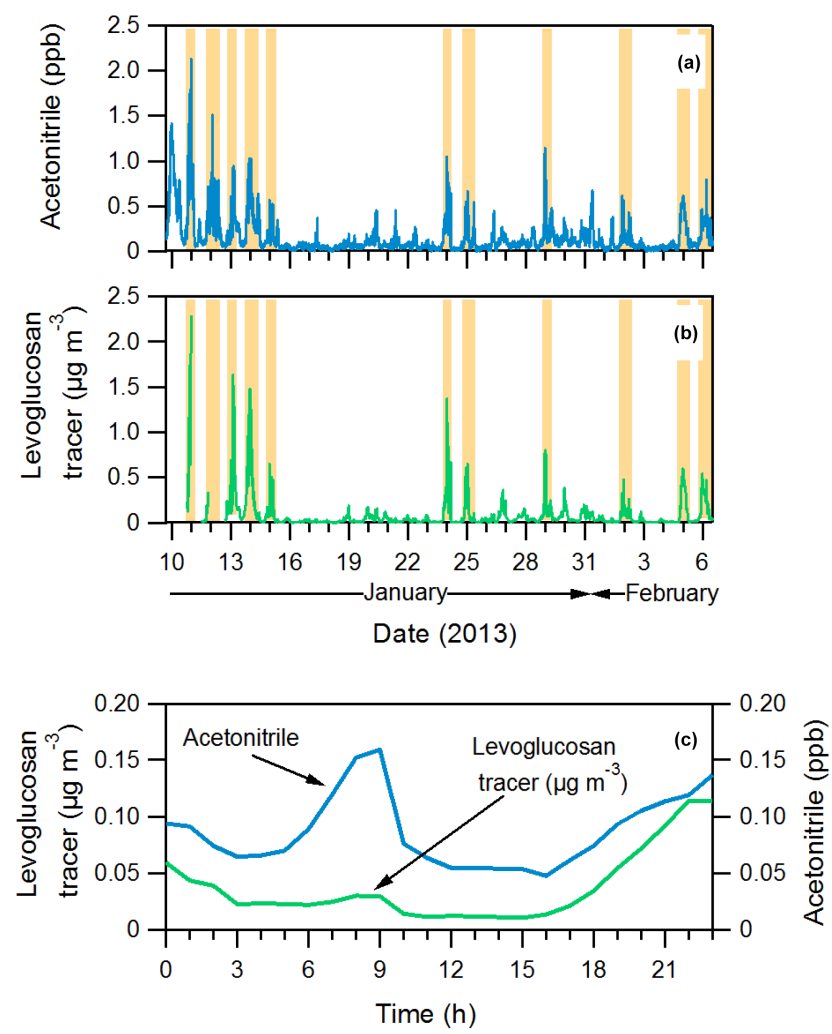

Figure 5. Time series of (a) AMS levoglucosan tracer $(m / z 60$ of the AMS) and (b) acetonitrile for the Athens winter campaign. Light brown indicates periods where wood burning contributed substantially to the total VOC and particulate levels. Also shown (c) are their average diurnal profiles.

on the typical values reported in the literature for several fuel types. The estimated EFs for the measured species are shown in Table 4.

Emission ratios (Table 5) for the gas and particulate species were calculated as $\Delta$ [species] / $\Delta \mathrm{CO}$ (Table 4), where $\Delta$ [species] is the difference in the concentration, of each compound, between the burning period and an adjacent reference period. This reference period was selected based on the lower acetonitrile, $\mathrm{CO}$, and $\mathrm{CO}_{2}$ concentrations at adjacent time periods (prior or later) to the period identified as biomass burning. The estimated ratios are given in Table 4 . Emission ratios for toluene, xylenes, and $\mathrm{C}_{9}$ and $\mathrm{C}_{10}$ aromatics seem to be greater than various SE, SW, and pine spruce fuels (Warneke et al., 2011). Acetic acid's and acetonitriles's emission ratios were lower than the values reported by Warneke et al. (2011). The modified combustion efficiency (MCE) calculated for these biomass burning periods was high (0.975-0.983), indicating a low contribution from smoldering-phase burning. 
Table 4. Emission factors $\left(\mathrm{g} \mathrm{kg}^{-1}\right)$ for VOCs and other species during biomass burning.

\begin{tabular}{|c|c|c|c|c|c|c|c|c|c|}
\hline \multicolumn{10}{|c|}{ Emission Factors $\mathrm{g} \mathrm{kg}^{-1}$ of fuel } \\
\hline Species & $\begin{array}{r}\text { Residential } \\
\text { heating } \\
\text { (This work) }\end{array}$ & $\begin{array}{r}\text { Savanna fires } \\
\text { (Sinha et al., } \\
2003)\end{array}$ & $\begin{array}{r}\text { Yucatán } \\
\text { Mexico } \\
\text { (Yokelson } \\
\text { et al., } \\
2009 \text { ) }\end{array}$ & $\begin{array}{r}\text { Pine-forest } \\
\text { understory } \\
\text { (Yokelson } \\
\text { et al., } \\
2013 \text { ) }\end{array}$ & $\begin{array}{r}\text { Coniferous } \\
\text { Canopy } \\
\text { (Yokelson } \\
\text { et al., } \\
2013 \text { ) }\end{array}$ & $\begin{array}{r}\text { African grass } \\
\text { (Stockwell } \\
\text { et al., } \\
2015)\end{array}$ & $\begin{array}{r}\text { Alfalfa } \\
\text { (Stockwell } \\
\text { et al., } \\
2015)\end{array}$ & $\begin{array}{r}\text { Black } \\
\text { spruce } \\
\text { (Stockwell } \\
\text { et al., } \\
2015)\end{array}$ & $\begin{array}{r}\text { Ponderosa } \\
\text { pine } \\
\text { (Stockwel } \\
\text { et al. } \\
2015 \text { ) }\end{array}$ \\
\hline $\mathrm{CO}_{2}$ & 1600 & $1700 \pm 60$ & $1641 \pm 40$ & $1668 \pm 72$ & $1670 \pm 128$ & $1565 \pm 14$ & $1352 \pm$ & $1724 \pm 35$ & $1594 \pm 109$ \\
\hline $\mathrm{SO}_{2}$ & $0.02 \pm 0.02$ & $0.43 \pm 0.30$ & $3.16 \pm 2.02$ & $1.06 \pm 0.39$ & $1.06 \pm 0.41$ & $0.95 \pm 0.28$ & $1.2 \pm 0.6$ & $0.93 \pm 0.01$ & \pm 0.27 \\
\hline $\mathrm{NO}_{x}$ (as $\left.\mathrm{NO}\right)$ & $1.6 \pm 0.2$ & $3.3 \pm 0.6$ & $4.19 \pm 3.33$ & $2.55 \pm 0.41$ & $2.40 \pm 1.47$ & 2.10 & 3.41 & 3.42 & 2.97 \\
\hline $\mathrm{CO}$ & $22.2 \pm 2.8$ & $68 \pm 30$ & $80.2 \pm 19.4$ & $72.2 \pm 26$ & $85.3 \pm 38.3$ & $22.6 \pm 4.8$ & $76.5 \pm 7.3$ & $46.5 \pm 8.7$ & $95.3 \pm 27$ \\
\hline Acetonitrile & $0.01 \pm 0.002$ & & 0.5 & $0.13 \pm 0.09$ & $0.14 \pm 0.06$ & $0.02 \pm 0.02$ & $0.67 \pm 0.11$ & $0.05 \pm 0.02$ & $0.20 \pm 0.11$ \\
\hline Formic acid & $0.05 \pm 0.01$ & $0.62 \pm 0.18$ & $1.53 \pm 1.11$ & $0.09 \pm 0.09$ & $0.22 \pm 0.18$ & $0.06 \pm 0.04$ & $0.14 \pm 0.16$ & $0.33 \pm 0.17$ & $0.96 \pm 0.45$ \\
\hline Ethanol & & & & $0.16 \pm 0.23$ & $0.04 \pm 0.02$ & & & & \\
\hline Acetone & $0.14 \pm 0.02$ & & 1.10 & $0.35 \pm 0.29$ & $0.37 \pm 0.2$ & $0.09 \pm 0.07$ & $0.82 \pm 0.11$ & $0.72 \pm 0.78$ & $0.82 \pm 0.49$ \\
\hline Acetic acid & $0.11 \pm 0.04$ & $2.4 \pm 0.9$ & $4.04 \pm 3.13$ & $1.33 \pm 1.27$ & $1.19 \pm 0.98$ & $0.72 \pm 0.47$ & $5.5 \pm 6.9$ & $1.6 \pm 0.9$ & $5.6 \pm 3.5$ \\
\hline Isoprene & $0.09 \pm 0.02$ & $0.04 \pm 0.02$ & & $0.07 \pm 0.06$ & $0.10 \pm 0.09$ & $0.02 \pm 0.02$ & $0.43 \pm 0.03$ & $0.44 \pm 0.25$ & $1.5 \pm 1.0$ \\
\hline Furan & & & & $0.20 \pm 0.21$ & $0.16 \pm 0.07$ & $0.06 \pm 0.04$ & $0.22 \pm 0.12$ & $0.12 \pm 0.04$ & $0.41 \pm 0.30$ \\
\hline MACR & $0.04 \pm 0.006$ & & & $0.05 \pm 0.04$ & $0.08 \pm 0.07$ & $0.07 \pm 0.07$ & $0.30 \pm 0.03$ & $0.23 \pm 0.12$ & $0.61 \pm 0.35$ \\
\hline MVK & & & & $0.22 \pm 0.17$ & $0.30 \pm 0.20$ & & & & \\
\hline MEK & $0.04 \pm 0.006$ & & 0.62 & $0.12 \pm 0.11$ & $0.12 \pm 0.06$ & $0.02 \pm 0.02$ & $0.29 \pm 0.06$ & $0.06 \pm 0.04$ & $0.21 \pm 0.14$ \\
\hline Benzene & $0.12 \pm 0.01$ & $0.18 \pm 0.09$ & 0.76 & $0.18 \pm 0.17$ & $0.62 \pm 0.59$ & $0.04 \pm 0.03$ & $0.53 \pm 0.26$ & $0.59 \pm 0.25$ & $1.29 \pm 0.90$ \\
\hline Toluene & $0.26 \pm 0.03$ & $0.13 \pm 0.10$ & & $0.14 \pm 0.12$ & $0.25 \pm 0.12$ & $0.03 \pm 0.02$ & $0.46 \pm 0.06$ & $2.4 \pm 1.2$ & $3.0 \pm 2.1$ \\
\hline Xylene & $26 \pm 0.03$ & & & $0.17^{*}$ & $0.18^{*}$ & $0.006 \pm 0.005^{*}$ & $0.15 \pm 0.02^{*}$ & $0.19 \pm 0.09^{*}$ & $0.18 \pm 0.08^{*}$ \\
\hline Monoterpenes & $0.08 \pm 0.02$ & & & $0.25 \pm 0.24$ & $0.62 \pm 0.46$ & $0.005 \pm 0.004$ & $0.12 \pm 0.02$ & $0.10 \pm 0.04$ & $0.22 \pm 0.16$ \\
\hline
\end{tabular}

* Sum of $m$-, $p$-, $o$-xylene, and ethyl benzene.

\section{VOC sources}

\subsection{Patras summer 2012 - PMF}

For the Patras PMF analysis of the PTR-MS data a fourfactor solution was selected. This choice is further discussed in the Supplement (Sect. S5.1 and S5.2). An $f_{\text {peak }}$ of zero was chosen based on the $m / z$ composition of the factors and the correlations of the factors to known external (BC and $\mathrm{NO}_{x}$ ) and internal (aromatic VOCs, biogenic VOCs) tracers (Supplement, Sect. S5.3). Solutions in the $f_{\text {peak }}$ range from -0.4 to 0.2 have only minor differences. Other solutions deriving from different $f_{\text {peak }}$ selections are also presented in the Supplement. The factors obtained were attributed to biogenic emissions (factor bVOC), traffic emissions (factor TRAF), oxygenated VOCs (factor OVOC), and oxygenated VOCs of biogenic origin (factor b-OVOC).

The bVOC factor included mainly isoprene $(m / z 69)$ and the monoterpenes $(m / z 137)$ (Fig. 6). There were small contributions by $m / z$ values $71,81,87$, and 101 . The factor average diurnal pattern has a peak at 15:00 LT. The factor showed weak correlations with the biogenic oxygenated organic aerosol (b-OOA) and the moderately oxygenated OA (M-OOA) $\left(R^{2}=0.20\right.$ and 0.22 respectively) as obtained by the PMF analysis of the AMS data (Kostenidou et al., 2015). This weak correlation is due to the fact that the b-OOA has been at least partially produced away from the measurement site. This highlights the challenges of combining gas- and particulate-phase measurements during source apportionment applications. Sunlight intensity also had a weak correlation $\left(R^{2}=0.24\right)$ with the bVOC factor. The factor also showed weak correlation $\left(R^{2}=0.29\right)$ with ambient temperature. These correlations improved to 0.28 and 0.35 respectively after shifting the time series of the factor earlier by $2 \mathrm{~h}$. This suggests that some of the biogenic components included in this factor are transported emissions to the site from nearby areas. Wind roses indicate that the higher concentrations (above the 75th percentile) were coming from ENE (Fig. S24).

Factor TRAF included the aromatic species $(\mathrm{m} / \mathrm{z}$ values 79, 93, 107, 121, and 135) as well as $m / z$ values 43, 59, 61, and 69 (Fig. 6). Some contribution by $\mathrm{m} / \mathrm{z}$ values 71 and 73 was also observed. Its diurnal profile as expected is similar to that of the aromatic species (Fig. 2) with one peak at 09:00 LT and one at 22:00 LT. The toluene to benzene ratio of the factor was 2.6, i.e., the same as the ratio for the third period. Correlations between this factor and $\mathrm{BC}$ were relatively high $\left(R^{2}=0.66\right)$. The two hydrocarbon-like OA factors (HOA-1 and HOA-2) reported by Kostenidou et al. (2015) showed $R^{2}$ of 0.49 and 0.43 with this factor respectively. The $\mathrm{PM}_{1}$ organonitrate calculated for the AMS measurements based on Farmer et al. (2010) also correlates well $\left(R^{2}=0.59\right)$ with the TRAF factor. The main source of this factor based on the diurnal profiles and the correlations seen is traffic in the city of Patras and the surrounding areas. This is consistent with the wind rose for this factor (Fig. S24), which points out that the higher emissions are located to the W-SW of the site where the city of Patras is 
Table 5. Emission ratios for biomass burning due to residential heating. Comparison with reported emission ratios from various biomass fuel types.

\begin{tabular}{|c|c|c|c|c|c|c|c|c|}
\hline \multicolumn{9}{|c|}{ Emission ratios $\left(\Delta\right.$ species / $\left.\Delta \mathrm{CO}, \mathrm{ppb}^{\mathrm{ppm}}{ }^{-1}\right)$} \\
\hline Species & $\begin{array}{r}\text { Residential } \\
\text { heating } \\
\text { (This work) }\end{array}$ & $\begin{array}{r}\text { SW fuels } \\
\text { (Warneke } \\
\text { et al., } \\
2011 \text { ) }\end{array}$ & $\begin{array}{r}\text { SE fuels } \\
\text { (Warneke } \\
\text { et al., } \\
2011 \text { ) }\end{array}$ & $\begin{array}{r}\text { Pine spruce } \\
\text { (Warneke } \\
\text { et al., } \\
2011 \text { ) }\end{array}$ & $\begin{array}{r}\text { African } \\
\text { grass } \\
\text { (Stockwell } \\
\text { et al., } \\
2015)\end{array}$ & $\begin{array}{r}\text { Alfalfa } \\
\text { (Stockwell } \\
\text { et al., } \\
2015)\end{array}$ & $\begin{array}{r}\text { Black } \\
\text { spruce } \\
\text { (Stockwell } \\
\text { et al., } \\
2015)\end{array}$ & $\begin{array}{r}\text { Ponderosa } \\
\text { pine } \\
\text { (Stockwell } \\
\text { et al., } \\
2015)\end{array}$ \\
\hline $\mathrm{SO}_{2}$ & $0.4 \pm 0.5$ & - & - & - & $18.8 \pm 5.4$ & $6.4 \pm 3.7$ & $10 \pm 2$ & $4.6 \pm 1.4$ \\
\hline $\mathrm{NO}_{x}$ & $52.7 \pm 9$ & - & - & - & 88 & 42 & 70 & 32 \\
\hline Acetonitrile & $0.32 \pm 0.05$ & 0.56 & 1.03 & 1.05 & $0.50 \pm 0.39$ & $6.0 \pm 0.9$ & $0.73 \pm 0.17$ & $1.4 \pm 0.6$ \\
\hline $\begin{array}{l}\text { Formic acid } \\
\text { Ethanol }\end{array}$ & $1.3 \pm 0.3$ & 0.77 & 1.08 & 1.0 & $1.65 \pm 0.81$ & $1.08 \pm 1.29$ & $4.1 \pm 1.5$ & $5.9 \pm 1.1$ \\
\hline Acetone & $2.9 \pm 0.5$ & 0.84 & 1.93 & 1.94 & $1.19 \pm 1.42$ & $5.2 \pm 0.5$ & $8.9 \pm 11$ & $3.9 \pm 1.1$ \\
\hline Acetic acid & $2.0 \pm 1.0$ & 4.84 & 13.61 & 8.19 & $13.2 \pm 6.8$ & $31 \pm 40$ & $15.6 \pm 6.4$ & $25.4 \pm 8.1$ \\
\hline Isoprene & $1.6 \pm 0.22$ & 0.53 & 1.38 & 1.57 & $0.33 \pm 0.27$ & $2.3 \pm 0.1$ & $3.7 \pm 1.6$ & $6.2 \pm 2.1$ \\
\hline Furan & & & & & $1.1 \pm 0.76$ & $1.2 \pm 0.6$ & $1.1 \pm 0.3$ & $1.6 \pm 0.65$ \\
\hline MVK + MACR & $0.7 \pm 0.1$ & 0.43 & 1.08 & 1.32 & $1.11 \pm 0.94$ & $1.6 \pm 0.3$ & $1.9 \pm 0.7$ & $2.5 \pm 0.7$ \\
\hline MEK & $0.7 \pm 0.2$ & 0.41 & 1.28 & 1.17 & $0.26 \pm 0.22$ & $1.5 \pm 0.3$ & $0.5 \pm 0.3$ & $1.8 \pm 0.5$ \\
\hline Benzene & $1.8 \pm 0.2$ & 0.86 & 0.83 & 2.29 & $0.57 \pm 0.3$ & $2.5 \pm 1.1$ & $4.5 \pm 1.2$ & $4.6 \pm 1.8$ \\
\hline Toluene & $3.3 \pm 0.8$ & 0.30 & 0.48 & 0.81 & $0.3 \pm 0.2$ & $1.8 \pm 0.1$ & $14.8 \pm 5.5$ & $9.0 \pm 3.5$ \\
\hline Xylenes & $2.8 \pm 0.6$ & 0.19 & 0.35 & 0.60 & $0.07 \pm 0.04$ & $0.5 \pm 0.04$ & $1.0 \pm 0.3$ & $1.0 \pm 0.4$ \\
\hline Monoterpenes & $0.7 \pm 0.2$ & 0.16 & 0.55 & 1.25 & $0.004 \pm 0.002$ & $0.33 \pm 0.03$ & $0.42 \pm 0.13$ & $0.46 \pm 0.19$ \\
\hline
\end{tabular}

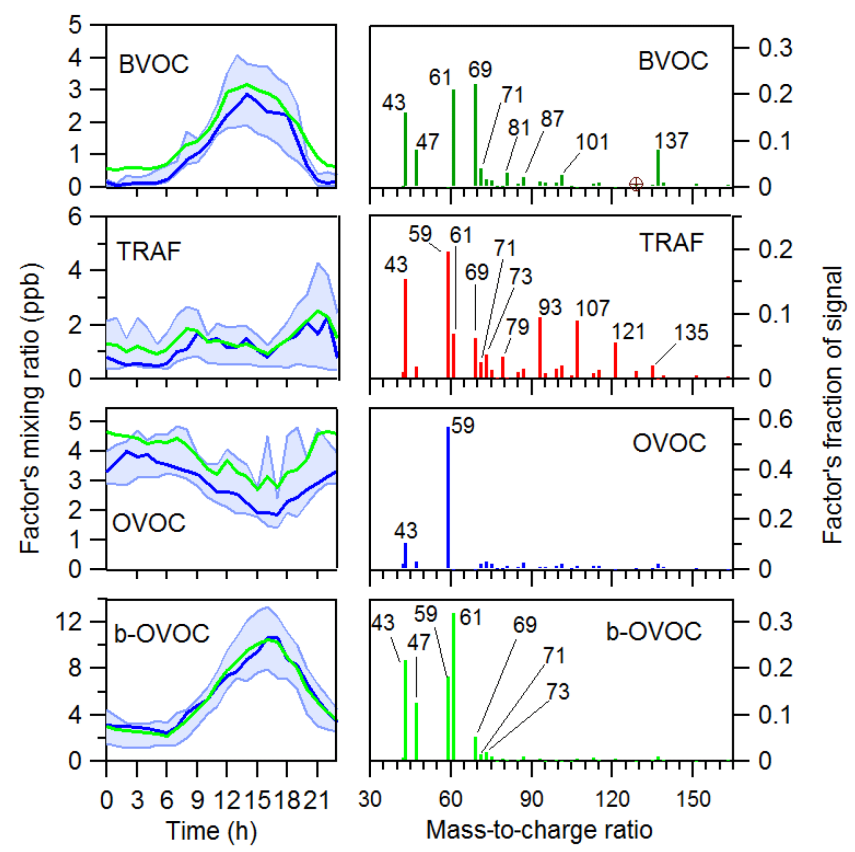

Figure 6. Results of Patras summer campaign PMF analysis. The left side shows the diurnal profiles of the factors. Green lines present the average values. The median value is shown with blue. The blue area is the interquartile range. The right side presents the $m / z$ composition of each factor as a fraction of signal for each $m / z$. located. Other sources, such as cooking emissions and ships, might contribute to this factor to some extent.

The OVOC factor mainly included acetone. Other $m / z$ values contributing to this factor were 43,47 , and 61 (Fig. 6). A weak correlation between the factor and the AMS's bOOA $\left(R^{2}=0.29\right)$ was observed. Additionally, low correlations were observed with particulate sulfate and nitrate $\left(R^{2}\right.$ of 0.23 and 0.18 respectively). The factor's diurnal pattern (Fig. 6) reveals elevated concentrations during the night and a minimum at 15:00 LT. The factor seems to be affected by mixing height changes and from long-range transport.

The last factor (b-OVOC) included oxygenated molecules (acetic acid, acetone, and formic acid/ethanol). Other $\mathrm{m} / \mathrm{z}$ values contributing to this factor were $\mathrm{m} / \mathrm{z} 43,69,71$, and 73 (Fig. 6). This factor includes mainly products of the oxidation of biogenic VOCs but also some primary VOCs. Approximately $70 \%$ of the measured isoprene during the $\mathrm{Pa}$ tras summer campaign was included by the PMF analysis in the bVOC factor (see also Fig. S20 in the Supplement). The remaining $30 \%$ was included in other factors, with $15 \%$ in the b-OVOC factor. This small amount of isoprene assigned to this factor can be justified as direct biogenic emissions that have originated far from the area close to the measurement site and have not yet reacted, or it can be due to the uncertainties in the PMF analysis. The factor was named b-OVOC (biogenic oxygenated VOCs) due to the formic acid, acetone, and acetic acid that it includes. The b-OVOC diurnal cycle is similar to that of the bVOC factor shifted by approximately $2 \mathrm{~h}$. Based on this diurnal cycle, the OVOC species that con- 


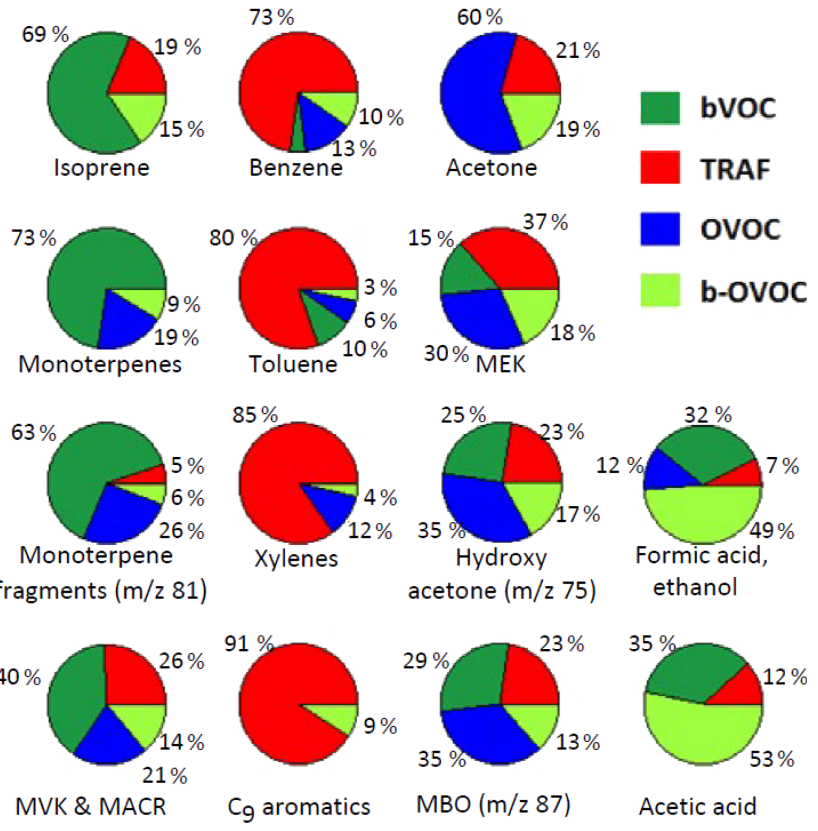

Figure 7. Species percentage (\%) attributed to the various PMF factors for the Patras summer campaign.

tribute to this factor are either products of the oxidation of biogenic molecules or direct biogenic emissions. Ambient temperature and sunlight intensity had a moderate correlation with the b-OVOC with $R^{2}$ of 0.35 and 0.32 respectively. A weak correlation $\left(R^{2}=0.27\right)$ of this factor was seen with the moderately oxygenated (M-OOA) by the AMS and no correlation $\left(R^{2}=0.08\right)$ was observed with the b-OOA. As in the $\mathrm{bVOC}$ factor, the greater concentrations of the b-OVOC factor are coming from the E-NE (Fig. S24). This supports the explanation that the b-OVOC factor is mostly oxidation products of local biogenic VOCs as well as temperature-sensitive emissions.

The contribution of each factor to the various VOC species is presented in Fig. 7. In total, $81 \%$ of isoprene $(\mathrm{m} / z 69)$ is included in the biogenic factors bVOC and b-OVOC. Monoterpene $m / z$ values (137 and 81 ) were mainly assigned by the PMF to the bVOC factor ( 73 and $63 \%$ respectively) and at smaller percentages to factor b-OVOC ( 9 and $6 \%$ respectively). Factor TRAF included the majority of the aromatic species (73-91\%). The rest of the aromatic species are assigned by the PMF to other factors. This is probably due to the combination of the low concentrations of most of the aromatics and the uncertainties in the PMF analysis. These values also provide an estimate of the uncertainty in these results. Patras summer PMF analysis demonstrates the importance of biogenic sources to the VOC budget of urban areas during summer.

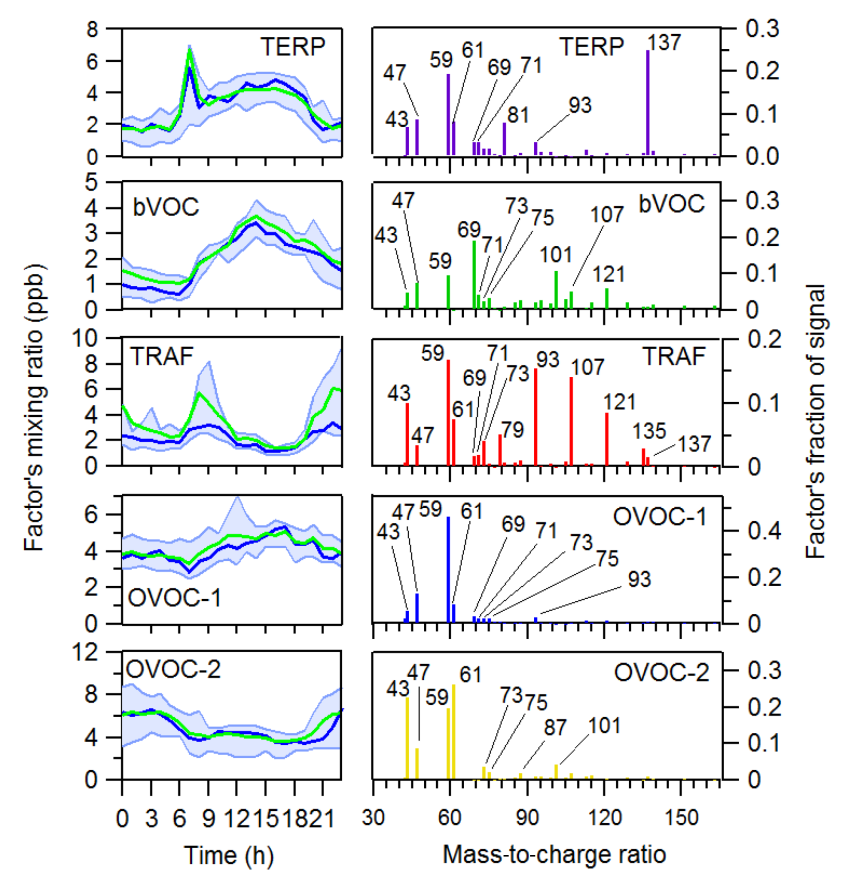

Figure 8. Results of Athens summer campaign PMF analysis. The left side shows the diurnal profiles of the factors. Green lines present the average values. The median value is shown with blue. The blue area is the interquartile range. The right side presents the $m / z$ composition of each factor as a fraction of signal for each $m / z$.

\subsection{Athens summer 2012 - PMF}

After the evaluation of various solutions, five factors were selected for this period with an $f_{\text {peak }}$ equal to zero (Supplement, Sect. S6.1, S6.2, S6.3). The factors were attributed to monoterpene species (factor TERP), other biogenic emissions (factor bVOC), traffic emissions (factor TRAF), and two oxygenated VOC factors (factor OVOC-1 and OVOC2).

For the Athens summer campaign, the local monoterpene emissions were separated by the PMF from the rest of the biogenic emissions, creating a new factor named TERP. The $\mathrm{m} / \mathrm{z}$ values 137 and 81 were the main components of this factor, and its diurnal profile (Fig. 8) has an early morning peak similar to that of the monoterpenes in this site (Fig. 3). Other $m / z$ values contributing to this factor were 43, 47, 59, 61, 69, 71, 73, 75, 77, and 93 (Fig. 8). No correlations $\left(R^{2}<0.05\right)$ were found between this factor and measured particulate species. These monoterpene emissions were due to local pine vegetation and their concentrations were affected by local mixing phenomena.

Factor bVOC was mainly composed of isoprene $(m / z 69)$ and isoprene hyperoxides $(\mathrm{m} / \mathrm{z} 101)$. A fraction of $\mathrm{m} / \mathrm{z}$ values $43,47,59,71,73,75,87,93$, and 121 was also included. Its diurnal profile (Fig. 8) peaked at 15:00 LT, similar to the bVOC factor for the Patras summer campaign. This factor 
had a weak correlation $\left(R^{2}=0.15\right)$ with the very oxygenated OA factor (V-OOA) obtained by the PMF analysis of the AMS data (Kostenidou et al., 2015). No correlation existed with the AMS M-OOA factor.

Factor TRAF included the aromatic species $(\mathrm{m} / \mathrm{z}$ values $79,93,107,121$, and 135$)$. Also, $m / z$ values $43,47,59,61$, and 73 contributed to this factor (Fig. 8). The diurnal profile is similar to that of the aromatic compounds (Fig. 3) with one peak at 09:00 and one at 22:00 LT. The toluene to benzene ratio of the factor was 3.1, indicating relatively fresh traffic emissions. Factor TRAF had moderate to high correlations with most of the species emitted by transportation sources: $\mathrm{NO}_{x}\left(R^{2}=0.69\right), \mathrm{BC}\left(R^{2}=0.45\right)$, AMS nitrate $\left(R^{2}=0.64\right)$ and AMS HOA-2 $\left(R^{2}=0.58\right)$. The factor's correlation with AMS HOA-1 was surprisingly weak $\left(R^{2}=0.16\right)$. This inconsistency is believed to derive from the inhomogeneity of the source distribution around the sampling site along with the shifting wind directions (Kostenidou et al., 2015). The highest concentrations (upper quartile) of this factor were observed during periods when the wind came from N-NE (Fig. S34). Particulate organonitrates (AMS) showed good correlation with factor TRAF $\left(R^{2}=0.65\right)$.

Factor OVOC-1 was dominated by acetone. Other $\mathrm{m} / \mathrm{z}$ values contributing to this factor were 43,47 , and 61 (Fig. 8). No correlation $\left(R^{2}<0.08\right)$ was found between this factor and other species. Its concentration had a modest afternoon peak. This factor is considered a mix of contributions by long-range transport and various anthropogenic and biogenic sources.

The OVOC-2 factor included mainly acetone $(m / z 59)$ and acetic acid $(m / z 61)$. The $m / z 43$ and 47 also contributed (Fig. 8). The factors concentrations were elevated during the night. The factor had correlations with $\mathrm{PM}_{1}$ nitrate $\left(R^{2}=\right.$ $0.49)$, HOA-1, and HOA-2 ( $R^{2}$ equal to 0.18 and 0.22 respectively), as well as with $\mathrm{V}$-OOA $\left(R^{2}=0.34\right)$ and $\mathrm{PM}_{1}$ sulfate $\left(R^{2}=0.32\right)$. Due to these correlations and its diurnal profile, this factor is believed to be linked to a mix of urban sources as well as long-range transport.

The fraction of some selected VOC species attributed to each factor is shown in Fig. 9. The majority (58\%) of isoprene is assigned to factor bVOC and smaller percentages to factors OVOC-1, TERP, and TRAF $(14,20$, and $7 \%$ respectively). Monoterpenes, $m / z$ values 137 and 81 , are almost exclusively included in factor TERP ( 84 and $76 \%$ respectively). The majority (55 to $73 \%$ ) of the aromatic species $(\mathrm{m} / \mathrm{z}$ values $79,93,121$, and 135$)$ are part of factor TRAF.

\subsection{Athens winter 2013 - PMF}

A five-factor solution and an $f_{\text {peak }}$ equal to zero were selected for the Athens winter campaign (Supplement, Sect. S7.1, S7.2, and S7.4). One factor was related to emissions originating from biomass burning (BBVOC). A factor for traffic emissions (factor TRAF) was identified, as well as one factor that was attributed mainly to industrial sources

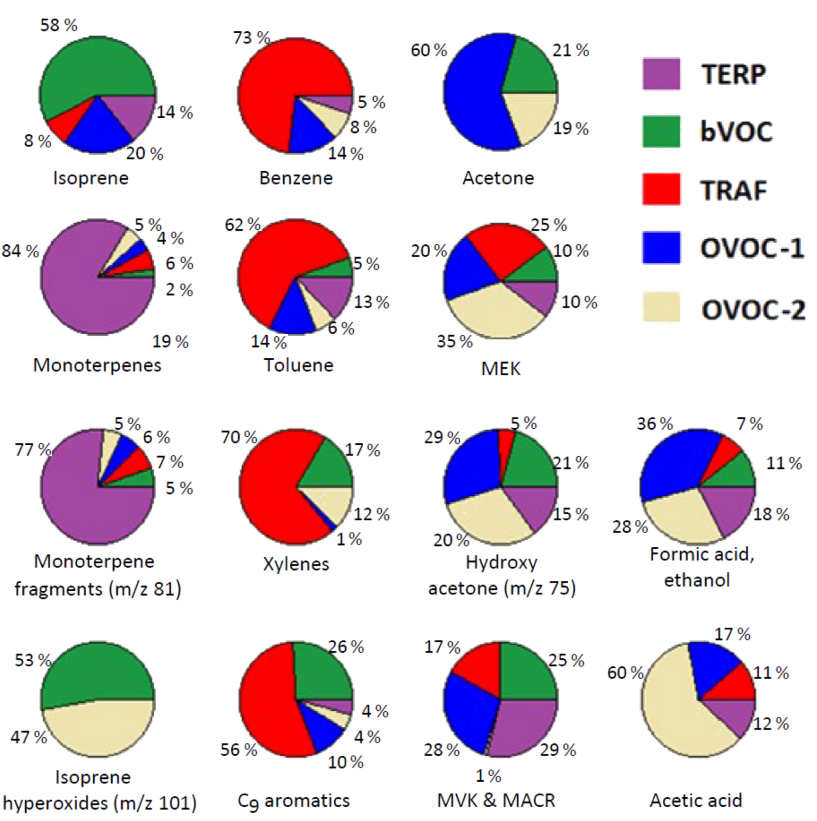

Figure 9. Species percentage (\%) attributed to the PMF factors for the Athens summer campaign.

(factor IND). Finally, two oxygenated VOC factors (OVOC1 and OVOC-2) were found. The measurement period that was selected for this PMF analysis did not include the first day of the measurements of the Athens winter campaign. Including the first day in the Athens winter campaign in the PMF analysis resulted in the separation of the biomass burning source into two or more factors for solutions with four or more factors (Supplement, Sect. S7.3). No distinct variation was seen for the favored wind direction between those BBVOC factors. Their time series (Fig. S41), though similar, showed significant differences for the first day of the campaign ( 9 and 10 January), when lower temperatures were recorded.

Factor BBVOC correlated strongly with the AMS $m / z 60$ $\left(R^{2}=0.92\right)$ linked to levoglucosan and also with acetonitrile $\left(R^{2}=0.80\right)$. It also had a high correlation $\left(R^{2}=0.84\right)$ with the AMS BBOA factor (Florou et al., 2016) and with other species emitted by biomass burning sources such as CO $\left(R^{2}=0.59\right)$ and $\mathrm{BC}\left(R^{2}=0.63\right)$. The factor mainly included acetone, isoprene, MVK and MACR, MEK, benzene, xylenes, $\mathrm{C}_{9}$ aromatics, and monoterpenes (Fig. 10). Due to the acetonitrile presence along with the high correlations obtained with known species of biomass burning origin (BBOA, AMS $m / z 60, \mathrm{CO}, \mathrm{BC}$ ), this factor was considered to derive from emissions of biomass burning. The diurnal profile (Fig. 10) of the factor is characteristic of residential heating use: moderate use during the early morning hours and high use during the night (from 18:00 to 24:00 LT). Wind roses (Fig. S46) indicate that the higher concentrations for this factor were coming from N-NE of the site. 


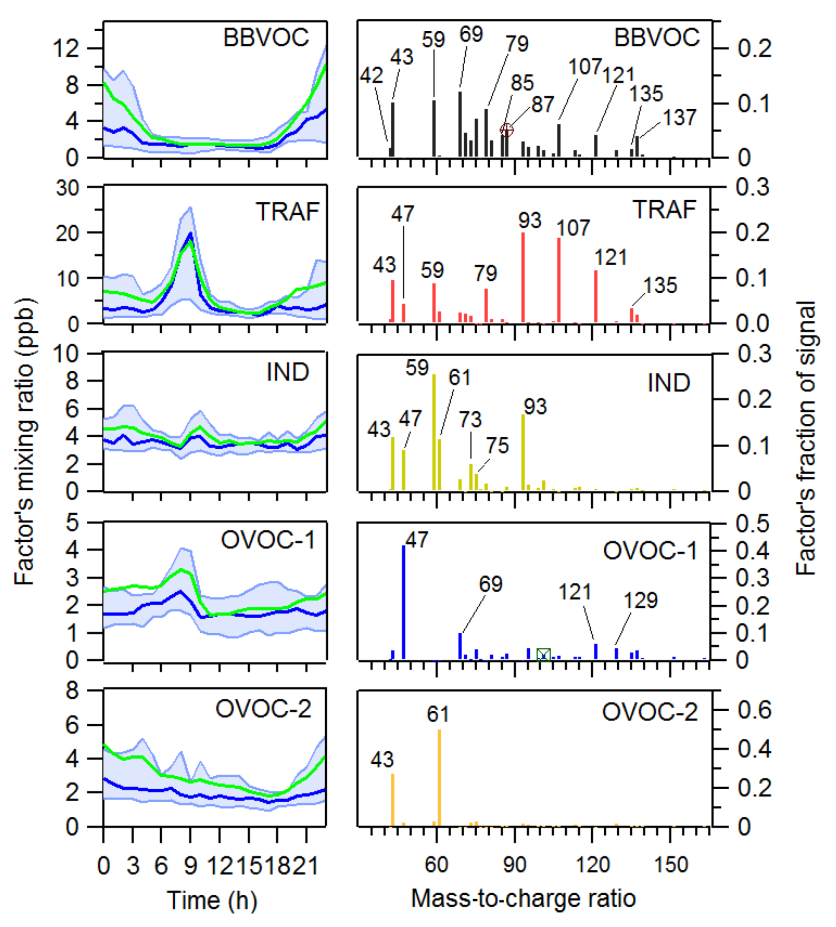

Figure 10. Results of Athens winter campaign PMF analysis. The left side shows the diurnal profiles of the factors. Green lines present the average values. The median value is shown with blue. The blue area is the interquartile range. The right side presents the $m / z$ composition of each factor as a fraction of signal for each $m / z$.

Factor TRAF has the same $m / z$ values as in the summer campaigns and is mainly linked to traffic. The aromatics are the main VOCs contributing to this factor. Other $\mathrm{m} / \mathrm{z}$ values that are present in considerable amounts are 43 and 59 (Fig. 10). The toluene to benzene ratio for this factor is 3.0, similar to the value (3.1) of the same factor during the summer campaign in Athens. Its diurnal profile includes one large peak corresponding to the morning rush hour and a smaller peak at approximately 19:00 LT (Fig. 10). The three factors related to traffic (factors named TRAF for the three studied campaigns) had a consistent $\mathrm{m} / \mathrm{z}$ spectrum with $R^{2}$ values ranging from 0.68 to 0.90 .

Factor IND mainly includes toluene and acetone (Fig. 10). Its diurnal pattern is relatively flat with slightly elevated concentrations during the night. A weak minimum is observed at 09:00 LT. Due to the presence of toluene this factor is considered of anthropogenic origin, probably related to industrial activities far from the site.

Factor OVOC-1 includes mainly formic acid $(\mathrm{m} / z 47)$ and some isoprene. The factor's diurnal profile (Fig. 10) was characterized by higher values during the early morning hours, peaking at 08:00 LT. After a significant decline in the morning it slowly increased during the rest of the day. No significant correlations were found between this factor and other measured species. Factor OVOC-1 could not be asso-
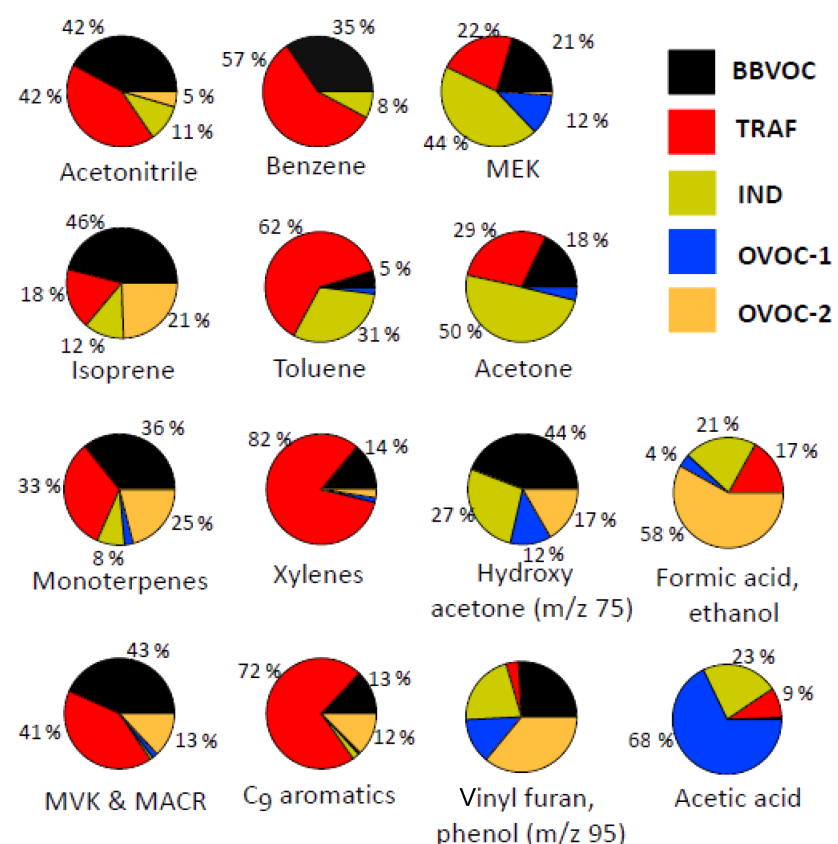

Figure 11. Species percentage (\%) attributed to the PMF factors for the Athens winter campaign for the five-factor solution.

ciated with any potential source. Wind roses (Fig. S46) indicate that the higher concentrations were coming from the $\mathrm{N}-\mathrm{NE}$ (city center) and that this factor is probably influenced by anthropogenic sources.

The last factor (OVOC-2) includes $m / z 43$ and acetic acid. The diurnal profile had elevated values during the night hours and was slowly decreasing through the day. It is probably associated with background concentrations of several VOCs (Fig. 10).

For this measurement period, over $35 \%$ of benzene, $14 \%$ of the xylenes, $13 \%$ of the $\mathrm{C}_{9}$ aromatics, and $14 \%$ of the $\mathrm{C}_{10}$ aromatics is estimated to be due to residential biomass burning (Fig. 11). Additionally, traditionally biogenic species such as $m / z 69$ and the monoterpenes were originating mainly (46 and $36 \%$ respectively) from residential biomass burning during this winter period. The Athens winter PMF analysis highlights the importance of biomass burning during winter for the VOC budget. Biomass burning and traffic were the major sources for the majority of the VOCs that were measured. However, biogenic sources had a limited contribution to the VOC budget.

\subsection{PMF overview}

Most of the urban source apportionment VOC studies separate the anthropogenic VOCs into several categories related to vehicle exhaust emissions, the evaporation of fuel, industrial solvents, diesel exhaust emissions, etc. (Brown et al., 2007; Tolga et al., 2007; Badol et al., 2008; Leuchner and Rappenglück, 2010; Yurdakul et al., 2013; Boynard et al., 
2014; Wang et al., 2014). In the present study the PMF analysis did not result in such separations since the VOC portfolio did not include light alkanes, which are usually included in datasets obtained by gas chromatographic (GC) techniques. The vehicular exhaust and LPG sources widely reported in the literature include a large fraction of these species; thus, such a separation was not favored by the PMF analysis.

\section{Conclusions}

Online measurements of VOCs and other gas and particulate species were performed in background urban sites of Greece during the summer and winter of 2012 and 2013. For the summer campaigns in Patras and Athens, the isoprene concentration was on average 1.0 and $0.7 \mathrm{ppb}$ respectively. The corresponding values for the monoterpenes were 0.3 and $0.9 \mathrm{ppb}$ with the elevated Athens concentrations originating mainly from local emissions. Typically, the isoprene concentrations peaked during the day with values up to $2 \mathrm{ppb}$, while during the night the concentrations were lower $(<0.5 \mathrm{ppb})$. Benzene, toluene, and the xylenes average concentrations were $0.12,0.28$, and $0.25 \mathrm{ppb}$ for Patras and $0.22,0.81$, and $0.67 \mathrm{ppb}$ for Athens respectively. These differences are considered modest if the population difference (one order of magnitude) is taken into account. During the morning rush hour aromatic compounds such as toluene, peaked up to $5 \mathrm{ppb}$ for Athens during the summer and $1 \mathrm{ppb}$ for Patras. Analogous concentrations were seen for the xylenes, while benzene values during rush hour were in the range of $1 \mathrm{ppb}$ for Athens and $0.3 \mathrm{ppb}$ for Patras.

During winter in Athens the average concentrations for isoprene and the monoterpenes were similar to the summer values $(1.1 \mathrm{ppb}$ for isoprene and $0.4 \mathrm{ppb}$ for the monoterpenes), indicating the importance of biomass burning sources of these compounds. Benzene, toluene, and the xylenes concentrations were elevated during winter $(1.0,2.3$, and $1.7 \mathrm{ppb}$ respectively) compared to summer, something attributed to the lower mixing height and the presence of additional sources. Concentrations up to $15 \mathrm{ppb}$ for acetic acid, toluene, and the xylenes were measured. For the majority of the measured species, elevated concentrations were observed during night, signifying the importance of biomass burning, which was enhanced by the lower mixing heights.

PMF analysis showed that traffic was the major aromatic VOC source in all three campaigns. A traffic-related factor was identified including more than $60 \%$ of benzene, $60 \%$ of toluene, $70 \%$ of the xylenes, and $70 \%$ of the $\mathrm{C}_{9}$ aromatics. Especially during summer, traffic dominated the above aromatic budget by contributing $73 \%$ of benzene for Patras and Athens and 80 and $62 \%$ of toluene for Patras and Athens respectively. In total, $85 \%$ of the xylenes in Patras and $70 \%$ in Athens were also apportioned to traffic.

The recent economic crisis along with the higher prices of fossil fuels has led to increased use of biomass burning for residential heating. Biomass burning emission ratios (ERs) and emission factors (EFs) due to residential heating were estimated. PMF analysis showed that the emissions of the aromatics by biomass burning were comparable to traffic emissions. Approximately $35 \%$ of benzene was due to biomass burning during the Athens winter campaign. Additionally, during winter, the "traditional" biogenic species, such as $m / z 69$, the monoterpenes, MVK, and MACR were originating mainly from biomass burning processes. During summer these biogenic species were almost exclusively linked to emissions from vegetation. During summer several oVOCs such as acetic acid, formic acid, and ethanol were also linked to biogenic emissions either directly or as secondary products.

\section{Data availability}

The VOC measurements in Patras and Athens during the three campaigns are available on request from Spyros Pandis (spyros@chemeng.upatras.gr).

\section{The Supplement related to this article is available online at doi:10.5194/acp-16-14825-2016-supplement.}

Acknowledgements. We thank A. Argyriou (Department of Physics - University of Patras) for providing the meteorological data, K. Eleftheriadis (N.C.S.R. "Demokritos") for providing the facilities for the Athens summer campaign, and E. Gerasopoulos (National Observatory of Athens - N.O.A) for providing the facilities for the Athens winter campaign. This research was cofinanced by Greece and the European Union through the education and lifelong learning operational program Thales: "Sources and physicochemical properties of fine and ultrafine aerosol particles that affect the regional climate of Greece". This research was also supported by the European Research Council Project ATMOPACS (Atmospheric Organic Particulate Matter, Air Quality and Climate studies) (grant agreement 267099) in coordination with project PEGASOS.

Edited by: J. Roberts

Reviewed by: two anonymous referees

\section{References}

Atkinson, R.: Atmospheric chemistry of VOCs and $\mathrm{NO}_{x}$, Atmos. Environ., 34, 2063-2101, 2000.

Akagi, S. K., Yokelson, R. J., Wiedinmyer, C., Alvarado, M. J., Reid, J. S., Karl, T., Crounse, J. D., and Wennberg, P. O.: Emission factors for open and domestic biomass burning for use in atmospheric models, Atmos. Chem. Phys., 11, 4039-4072, doi:10.5194/acp-11-4039-2011, 2011. 
Badol, C., Locoge, N., and Galloo, J.: Using a source-receptor approach to characterize VOC behavior in a French urban area influenced by industrial emissions Part II: Source contribution assessment using the Chemical Mass Balance (CMB) model, Sci. Total Environ., 389, 429-440, 2008.

Boynard, A., Borbon, A., Leonardis, T., Barletta, B., Meinardi, S., Blake, D., and Locoge, N.: Spatial and seasonal variability of measured anthropogenic nonmethane hydrocarbons in urban atmospheres: Implication on emission ratios, Atmos. Environ., 82, 258-267, 2014.

Brown, S., Frankel, A., and Hafner, H.: Source apportionment of VOCs in the Los Angeles area using positive matrix factorization, Atmos. Environ., 41, 227-237, 2007.

Colomb, A., Yassaa, N., Williams, J., Peekend, I., and Lochted, K.: Screening volatile organic compounds (VOCs) emissions from five marine phytoplankton species by head space gas chromatography/mass spectrometry (HS-GC/MS), J. Environ. Monitor., 10, 325-330, 2008.

Crippa, M., Canonaco, F., Slowik, J. G., El Haddad, I., DeCarlo, P. F., Mohr, C., Heringa, M. F., Chirico, R., Marchand, N., Temime-Roussel, B., Abidi, E., Poulain, L., Wiedensohler, A., Baltensperger, U., and Prévôt, A. S. H.: Primary and secondary organic aerosol origin by combined gas-particle phase source apportionment, Atmos. Chem. Phys., 13, 8411-8426, doi:10.5194/acp-13-8411-2013, 2013.

Crutzen, P. and Andreae, M.: Biomass burning in the tropics: Impact on atmospheric chemistry and biogeochemical cycles, Science, 250, 1669-1678, 1990.

Davison, B., Taipale, R., Langford, B., Misztal, P., Fares, S., Matteucci, G., Loreto, F., Cape, J. N., Rinne, J., and Hewitt, C. N.: Concentrations and fluxes of biogenic volatile organic compounds above a Mediterranean macchia ecosystem in western Italy, Biogeosciences, 6, 1655-1670, doi:10.5194/bg-6-16552009, 2009.

DeGouw, J. and Warneke, C.: Measurements of volatile organic compounds in the earth's atmosphere using proton-transferreaction mass spectrometry, Mass Spectrom. Rev., 26, 223-257, 2007.

DeGouw, J. A., Goldan, P. D., Warneke, C., Kuster, W. C., Roberts, J. M., Marchewka, M., Bertman, S. B., Pszenny, A. A. P., and Keene, W. C.: Validation of proton transfer reaction-mass spectrometry (PTR-MS) measurements of gas-phase organic compounds in the atmosphere during the New England Air Quality Study (NEAQS) in 2002, J. Geophys. Res., 108, 4682, doi:10.1029/2003JD003863, 2003.

Draxler, R. R. and Rolph, G. D.: HYSPLIT (HYbrid Single-Particle Lagrangian Integrated Trajectory) Model access via NOAA already Website. NOAA Air Resources Laboratory, Silver Spring, MD, available at: http://ready.arl.noaa.gov/HYSPLIT.php (last access: November 2016), 2013.

Dunlea, E. J., Herndon, S. C., Nelson, D. D., Volkamer, R. M., San Martini, F., Sheehy, P. M., Zahniser, M. S., Shorter, J. H., Wormhoudt, J. C., Lamb, B. K., Allwine, E. J., Gaffney, J. S., Marley, N. A., Grutter, M., Marquez, C., Blanco, S., Cardenas, B., Retama, A., Ramos Villegas, C. R., Kolb, C. E., Molina, L. T., and Molina, M. J.: Evaluation of nitrogen dioxide chemiluminescence monitors in a polluted urban environment, Atmos. Chem. Phys., 7, 2691-2704, doi:10.5194/acp-7-2691-2007, 2007.
Dunne, E., Galbally, I., Lawson, S., and Patti, A.: Interference in the PTR-MS measurement of acetonitrile at $m / z 42$ in polluted urban air - A study using switchable reagent ion PTR-MS, Int. J. Mass Spectrom., 319-320, 40-47, 2012.

Farmer, D. K., Matsunaga, A., Docherty, K. S., Surratt, J. D., Sienfeld, J. H., Ziemann, P. J., and Jimenez, J. L.: Response of an aerosol mass spectrometer to organonitrates and organosulfates and implications on atmospheric chemistry, P. Natl. Acad. Sci. USA, 107, 6670-6675, doi:10.1073/pnas.0912340107, 2010.

Filella, I. and Penuelas, J.: Daily, weekly, and seasonal time courses of VOC concentrations in a semi-urban area near Barcelona, Atmos. Environ., 40, 7752-7769, 2006.

Flesca, N. G., Cicolella, A., Bates, M., and Bastin, E.: Pilot study of personal indoor and outdoor exposure to benzene, formaldehyde and acetaldehyde, Environ. Sci. Pollut. R., 6, 95-102, 1999.

Florou, K., Papanastasiou, D. K., Pikridas, M., Kaltsonoudis, C., Louvaris, E., Gkatzelis, E., Patoulias, D., Mihalopoulos, N., and Pandis, S. N.: The contribution of wood burning and other pollution sources to wintertime organic aerosol levels in two Greek cities, Atmos. Chem. Phys. Discuss., doi:10.5194/acp-2016-721, in review, 2016.

Goldstein, A. H. and Galbally, I. E.: Known and unexplored organic constituents in the Earth's Atmosphere, Environ. Sci. Technol., 41, 1515-1521, 2007.

Goldstein, A. H. and Schade, G. W.: Quantifying biogenic and anthropogenic contributions to acetone concentrations in a rural environment, Atmos. Environ., 34, 4997-5006, 2000.

Hallquist, M., Wenger, J. C., Baltensperger, U., Rudich, Y., Simpson, D., Claeys, M., Dommen, J., Donahue, N. M., George, C., Goldstein, A. H., Hamilton, J. F., Herrmann, H., Hoffmann, T., Iinuma, Y., Jang, M., Jenkin, M. E., Jimenez, J. L., Kiendler-Scharr, A., Maenhaut, W., McFiggans, G., Mentel, Th. F., Monod, A., Prévôt, A. S. H., Seinfeld, J. H., Surratt, J. D., Szmigielski, R., and Wildt, J.: The formation, properties and impact of secondary organic aerosol: current and emerging issues, Atmos. Chem. Phys., 9, 5155-5236, doi:10.5194/acp-9-51552009, 2009.

Holzinger, R., Williams, J., Salisbury, G., Klüpfel, T., de Reus, M., Traub, M., Crutzen, P. J., and Lelieveld, J.: Oxygenated compounds in aged biomass burning plumes over the Eastern Mediterranean: evidence for strong secondary production of methanol and acetone, Atmos. Chem. Phys., 5, 39-46, doi:10.5194/acp-5-39-2005, 2005.

Kampa, M. and Castanas, E.: Human health effects of air pollution, Environ. Pollut., 151, 362-367, 2008.

Karl, T., Jobson, T., Kuster, W. C., Williams, E., Stutz, J., Shetter, R., Hall, S. R., Goldan, P., Fehsenfeld, F., and Lindinger, W.: Use of proton-transfer-reaction mass spectrometry to characterize volatile organic compound sources at the La Porte super site during the Texas Air Quality Study 2000, J. Geophys. Res., 108, 4508, doi:10.1029/2002JD003333, 2003.

Karl, T. G., Christian, T. J., Yokelson, R. J., Artaxo, P., Hao, W. M., and Guenther, A.: The Tropical Forest and Fire Emissions Experiment: method evaluation of volatile organic compound emissions measured by PTR-MS, FTIR, and GC from tropical biomass burning, Atmos. Chem. Phys., 7, 5883-5897, doi:10.5194/acp-7-5883-2007, 2007. 
Kesselmeier, J. and Staudt, M.: Biogenic Volatile Organic Compounds (VOC): An Overview on Emission, Physiology and Ecology, J. Atmos. Chem., 33, 23-88, 1999.

Kettle, A. J. and Andreae, M. O.: Flux of dimethylsulfide from the oceans: A comparison of updated data sets and flux models, J. Geophys. Res., 105, 26793-26808, 2000.

Koppmann, R.: Volatile organic compounds in the atmosphere, Blackwell Publishing Ltd, University of Wuppertal, Germany, 2007.

Kostenidou, E., Florou, K., Kaltsonoudis, C., Tsiflikiotou, M., Vratolis, S., Eleftheriadis, K., and Pandis, S. N.: Sources and chemical characterization of organic aerosol during the summer in the eastern Mediterranean, Atmos. Chem. Phys., 15, 11355-11371, doi:10.5194/acp-15-11355-2015, 2015.

Kouvarakis, G., Vrekoussis, M., Michalopoulos, N., Kourtidis, K., and Rappenglueck, B.: Spatial and temporal variability of tropospheric ozone $\left(\mathrm{O}_{3}\right)$ in the boundary layer above the Aegean Sea (eastern Mediterranean), J. Geophys. Res., 107, 8137, doi:10.1029/2000JD000081, 2002.

Kristensson, A., Johansson, C., Westerholm, R., Swietlicki, E., Gidhagen, L., Wideqvist, U., and Vesely, V.: Real-world traffic emission factors of gases and particles measured in a road tunnel in Stockholm, Sweden, Atmos. Environ., 38, 657-673, 2004.

Lanz, V. A., Alfarra, M. R., Baltensperger, U., Buchmann, B., Hueglin, C., and Prévôt, A. S. H.: Source apportionment of submicron organic aerosols at an urban site by factor analytical modelling of aerosol mass spectra, Atmos. Chem. Phys., 7, 15031522, doi:10.5194/acp-7-1503-2007, 2007.

Leuchner, M. and Rappenglück, B.: VOC source-receptor relationships in Houston during TexAQS-II, Atmos. Environ., 44, 40564067, 2010.

Lindinger, W., Hansel, A., and Jordan, A.: On-line monitoring of volatile organic compounds at pptv levels by means of ProtonTransfer-Reaction Mass Spectrometry (PTR-MS) Medical applications, food control and environmental research, Int. J. Mass Spectrom., 173, 191-241, 1998.

Meskhidze, N. and Nenes, A.: Phytoplankton and cloudiness in the Southern Ocean, Science, 314, 1419-1423, 2006.

Millet, D. B., Donahue, N. M., Pandis, S. N., Polidori, A., Stanier, C. O., Turpin, B. J., and Goldstein, A. H.: Atmospheric volatile organic compound measurements during the Pittsburgh Air Quality Study: Results, interpretation, and quantification of primary and secondary contributions, J. Geophys. Res., 110, D07S07, doi:10.1029/2004JD004601, 2005.

Paatero, P. and Tapper, U.: Positive matrix factorization - a nonnegative factor model with optimal utilization of error-estimates of data values, Environmetrics, 5, 111-126, 1994.

Pikridas, M., Tasoglou, A., Florou, K., and Pandis, S. N.: Characterization of the origin of fine particulate matter in a medium size urban area in the Mediterranean, Atmos. Environ., 80, 264-274, 2013.

Rappenglück, B., Fabian, P., Kalabokas, P., Viras, L., and Ziomas, I. C.: Quasi-continuous measurements of non-methane hydrocarbons (NMHC) in the greater Athens area during MEDCAPHOTTRACE, Atmos. Environ., 32, 2103-2121, 1998.

Roberts, J. M., Fehsenfeld, F. C., Liu, S. C., Bollinger, M. J., Hahn, C., Albritton, D. L., and Sievers, R. E.: Measurements of aromatic hydrocarbon ratios and $\mathrm{NO}_{x}$ concentrations in the rural troposphere. Observation of air mass photochemical aging and $\mathrm{NO}_{x}$ removal, Atmos. Environ., 18, 2421-2432, 1984.

Salisbury, G., Williams, J., Holzinger, R., Gros, V., Mihalopoulos, N., Vrekoussis, M., Sarda-Estève, R., Berresheim, H., von Kuhlmann, R., Lawrence, M., and Lelieveld, J.: Ground-based PTR-MS measurements of reactive organic compounds during the MINOS campaign in Crete, July-August 2001, Atmos. Chem. Phys., 3, 925-940, doi:10.5194/acp-3-925-2003, 2003.

Sarkar, C., Sinha, V., Kumar, V., Rupakheti, M., Panday, A., Mahata, K. S., Rupakheti, D., Kathayat, B., and Lawrence, M. G.: Overview of VOC emissions and chemistry from PTR-TOFMS measurements during the SusKat-ABC campaign: high acetaldehyde, isoprene and isocyanic acid in wintertime air of the Kathmandu Valley, Atmos. Chem. Phys., 16, 3979-4003, doi:10.5194/acp-16-3979-2016, 2016.

Seco, R., Peñuelas, J., Filella, I., Llusià, J., Molowny-Horas, R., Schallhart, S., Metzger, A., Müller, M., and Hansel, A.: Contrasting winter and summer VOC mixing ratios at a forest site in the Western Mediterranean Basin: the effect of local biogenic emissions, Atmos. Chem. Phys., 11, 13161-13179, doi:10.5194/acp11-13161-2011, 2011.

Sinha, P., Hobbs, P. V., Yokelson, R. J., Bertschi, I. T., Blake, D. R., Simpson, I. J., Gao, S., Kirchstetter, T. W., and Novakov, T.: Emissions of trace gases and particles from savanna fires in southern Africa, J.Geophys. Res., 108, 8487 doi:10.1029/2002JD002325, 2003.

Sinha, V., Kumar, V., and Sarkar, C.: Chemical composition of premonsoon air in the Indo-Gangetic Plain measured using a new air quality facility and PTR-MS: high surface ozone and strong influence of biomass burning, Atmos. Chem. Phys., 14, 59215941, doi:10.5194/acp-14-5921-2014, 2014.

Stockwell, C. E., Veres, P. R., Williams, J., and Yokelson, R. J.: Characterization of biomass burning emissions from cooking fires, peat, crop residue, and other fuels with high-resolution proton-transfer-reaction time-of-flight mass spectrometry, Atmos. Chem. Phys., 15, 845-865, doi:10.5194/acp-15-845-2015, 2015.

Stohl, A., Forster, C., Frank, A., Seibert, P., and Wotawa, G.: Technical note: The Lagrangian particle dispersion model FLEXPART version 6.2, Atmos. Chem. Phys., 5, 2461-2474, doi:10.5194/acp-5-2461-2005, 2005.

Slowik, J. G., Vlasenko, A., McGuire, M., Evans, G. J., and Abbatt, J. P. D.: Simultaneous factor analysis of organic particle and gas mass spectra: AMS and PTR-MS measurements at an urban site, Atmos. Chem. Phys., 10, 1969-1988, doi:10.5194/acp-10-19692010, 2010.

Taipale, R., Ruuskanen, T. M., Rinne, J., Kajos, M. K., Hakola, H., Pohja, T., and Kulmala, M.: Technical Note: Quantitative long-term measurements of VOC concentrations by PTR-MS measurement, calibration, and volume mixing ratio calculation methods, Atmos. Chem. Phys., 8, 6681-6698, doi:10.5194/acp8-6681-2008, 2008.

Tassi, F., Capaccioni, B., Capecchiacci, F., and Vaselli, O.: Nonmethane Volatile Organic Compounds (VOCs) at El Chichón volcano (Chiapas, México): Geochemical features, origin and behavior, Geofísica Internacional, 48, 85-95, 2009.

Tassi, F., Capecchiacci, F., Giannini, L., Vougioukalakis, G. E., and Vaselli, O.: Volatile organic compounds (VOCs) in air from Nisy- 
ros Island (Dodecanese Archipelago, Greece): Natural versus anthropogenic sources, Environ. Pollut., 180, 111-121, 2013.

Tolga, E., Cetin, B., Cetin, E., Bayram, A., and Odabasi, M.: Characterization of volatile organic compounds (VOCs) and their sources in the air of Izmir, Turkey, Environ. Monit. Assess., 133, 149-160, 2007.

Ulbrich, I. M., Canagaratna, M. R., Zhang, Q., Worsnop, D. R., and Jimenez, J. L.: Interpretation of organic components from Positive Matrix Factorization of aerosol mass spectrometric data, Atmos. Chem. Phys., 9, 2891-2918, doi:10.5194/acp-9-2891-2009, 2009.

Vlasenko, A., Slowik, J. G., Bottenheim, J. W., Brickell, P. C., Chang, R. Y.-W., Macdonald, A. M., Shantz, N. C., Sjostedt, S. J., Wiebe, H. A., Leaitch, W. R., and Abbatt, J. P. D.: Measurements of VOCs by proton transfer reaction massspectrometry at a rural Ontario site: Sources and correlation to aerosol composition, J. Geophys. Res., 114, D21305, doi:10.1029/2009JD012025, 2009.

Wang, M., Shao, M., Chen, W., Yuan, B., Lu, S., Zhang, Q., Zeng, L., and Wang, Q.: A temporally and spatially resolved validation of emission inventories by measurements of ambient volatile organic compounds in Beijing, China, Atmos. Chem. Phys., 14, 5871-5891, doi:10.5194/acp-14-5871-2014, 2014.

Warneke, C., Roberts, J. M., Veres, P., Gilman, J., Kuster, W. C., Burling, I., Yokelson, R., and DeGouw, J. A.: VOC identification and inter-comparison from laboratory biomass burning using PTR-MS and PIT-MS, Int. J. Mass Spectrom., 303, 6-14, 2011.
Yokelson, R. J., Crounse, J. D., DeCarlo, P. F., Karl, T., Urbanski, S., Atlas, E., Campos, T., Shinozuka, Y., Kapustin, V., Clarke, A. D., Weinheimer, A., Knapp, D. J., Montzka, D. D., Holloway, J., Weibring, P., Flocke, F., Zheng, W., Toohey, D., Wennberg, P. O., Wiedinmyer, C., Mauldin, L., Fried, A., Richter, D., Walega, J., Jimenez, J. L., Adachi, K., Buseck, P. R., Hall, S. R., and Shetter, R.: Emissions from biomass burning in the Yucatan, Atmos. Chem. Phys., 9, 5785-5812, doi:10.5194/acp-9-5785-2009, 2009.

Yokelson, R. J., Burling, I. R., Gilman, J. B., Warneke, C., Stockwell, C. E., de Gouw, J., Akagi, S. K., Urbanski, S. P., Veres, P., Roberts, J. M., Kuster, W. C., Reardon, J., Griffith, D. W. T., Johnson, T. J., Hosseini, S., Miller, J. W., Cocker III, D. R., Jung, H., and Weise, D. R.: Coupling field and laboratory measurements to estimate the emission factors of identified and unidentified trace gases for prescribed fires, Atmos. Chem. Phys., 13, 89-116, doi:10.5194/acp-13-89-2013, 2013.

Yuan, B., Shao, M,. deGouw, J., Parrish, D. D., Lu, S., Wang, M., Zeng, L., Zhang, Q., Song, Y., Zhang, J., and Hu, M.: Volatile organic compounds (VOCs) in urban air: How chemistry affects the interpretation of positive matrix factorization (PMF) analysis, J. Geophys. Res., 117, D24302, doi:10.1029/2012JD018236, 2012.

Yurdakul, S., Civan, M., and Tuncel, G.: Volatile organic compounds in suburban Ankara atmosphere, Turkey: Sources and variability, Atmos. Res., 120, 298-311, 2013. 